NBER WORKING PAPER SERIES

\title{
THE TAXATION OF EXECUTIVE COMPENSATION
}

\author{
Brian J. Hall \\ Jeffrey B. Liebman \\ Working Paper 7596 \\ http://www.nber.org/papers/w7596 \\ NATIONAL BUREAU OF ECONOMIC RESEARCH \\ 1050 Massachusetts Avenue \\ Cambridge, MA 02138 \\ March 2000
}

This paper was prepared for the NBER's Tax Policv and the Economv. We thank James Poterba (the editor) for helpful suggestions and compensation consultants Robert Greenberg and Scott Olsen (of Towers Perrin) and Fred Cook (of Frederic W. Cook and Company) for helpful insights and background information. We thank Paul Gompers and Andrew Metrick for providing us with the data on the share ownership of large institutional investors, David Heilman whose Harvard undergraduate thesis first provoked us to think about these issues, and Austan Goolsbee, Gerald Auten, and Kevin Murphy for comments on an earlier draft. Gabriel Leon, Humayun Khalid and Katya Rosenblatt provided excellent research assistance. The views expressed herein are those of the authors and are not necessarily those of the National Bureau of Economic Research.

(C) 2000 by Brian J. Hall and Jeffrey B. Liebman. All rights reserved. Short sections of text, not to exceed two paragraphs, may be quoted without explicit permission provided that full credit, including $(\mathcal{O}$ notice, is given to the source. 
The Taxation of Executive Compensation

Brian J. Hall and Jeffrey B. Liebman

NBER Working Paper No. 7596

March 2000

JEL No.G34, H2, J33

\begin{abstract}
Over the past 20 years, there has been a dramatic increase in the share of executive compensation paid through stock options. In this paper, we examine the extent to which tax policy has influenced the composition of executive compensation, and discuss the implications of rising stock-based pay for tax policy. We begin by describing the tax rules for executive pay in detail and analyzing how changes in various tax rates affect the tax advantages of stock options relative to salary and bonus. Our empirical analysis leads to three conclusions. First, there is little evidence that tax changes have played a major role in the dramatic explosion in executive stock option pay since 1980. Although the tax advantage of options has approximately doubled since the early 1980s, options currently have only a slight tax advantage relative to cash - approximately $\$ 4$ per $\$ 100$ of pre-tax compensation to the executive. A more convincing story for the dramatic explosion in stock options involves changes in corporate governance and the market for corporate control. For example, there is a strong correlation between the fraction of shares held by large institutional investors and the fraction of executive pay in the form of stock options, a result that holds both longitudinally and cross-sectionally. Second, we find evidence that the million dollar rule (which limited the corporate deductibility of non-performance-related executive compensation to $\$ 1$ million) led firms to adjust the composition of their pay away from salary and toward "performance related pay," although our estimates suggest that substitution was minor. We find no evidence that the regulation decreased the level of total compensation. Third, we examine whether there is evidence for significant shifting of the timing of option exercises in response to changes in tax rates. After replicating the Goolsbee (1999) result regarding taxshifting with our data for the 1993 tax reform, we show that no such shifting occurred in either of the two tax reforms of the $1980 \mathrm{~s}$. Moreover, we find evidence that much of the unusually large level of option exercises in 1992 was the result of the rising stock market rather than the change in marginal tax rates.
\end{abstract}

Brian J. Hall

Harvard Business School

Harvard University, Baker 185

Boston, MA 02163

and NBER

bhall@hbs.edu
Jeffrey B. Liebman

John F. Kennedy School of Government Harvard University Cambridge, MA 02138 and NBER jeffrey_liebman@harvard.edu 


\section{Introduction}

Over the past 15 years, there has been a major change in the way that American executives, particularly CEOs, are paid. For many executives, annual stock option grants are now greater than cash compensation (salary and bonus). Annual changes in CEO wealth from revaluations of stock and stock option holdings completely swamp cash compensation, and provide substantial pay-to-performance sensitivity. All of this is a dramatic change from the early 1980s when the median stock option grant to top executives was zero.

In this paper, we examine the extent to which tax policy has influenced the composition of executive compensation, and discuss the implications of rising stock-based pay for tax policy. Because top executives manage assets worth billions of dollars, their compensation arrangements and the incentives they face are of substantial importance to the performance of the U.S. economy. Because top executives have very high incomes, their responsiveness to taxation has important revenue and efficiency implications.

We conduct a broad analysis of the taxation of executives. We begin by studying how tax rates affect the degree to which options are favored relative to cash and how the tax advantage of options has changed over time in response to changes in corporate, personal, and capital gains tax rates. Although the tax advantage of options has approximately doubled since the early 1980s, options currently have only a slight tax advantage relative to cash - approximately $\$ 4$ per $\$ 100$ of pre-tax compensation.

We then analyze what we believe to be the three central policy questions regarding the taxation of executive pay. First, we examine the extent to which the stock option explosion has been influenced by the many changes in tax rates over the past 20 years. The evidence suggests that changes in taxation have likely had a very modest influence on the option explosion. Instead, changes in corporate governance, especially in the role of large institutional investors, appear to have provided the main impetus for the increase in stock-based pay.

Second, we examine the effectiveness of tax policies aimed at curbing what is deemed by some to be excessive levels of executive compensation. Section 162(m) of the Internal Revenue Code (the "million dollar rule") was enacted in 1993, which put a $\$ 1$ million limit on the deductibility (against corporate profits) of non-performance related executive pay. Although we find evidence that this rule led to a shift in the composition of pay - away from salary and toward more performance-related bonuses and stock options - our evidence suggests that the 
magnitude of this substitution was small. We find no evidence that the million dollar rule decreased total executive compensation.

Third, we analyze the degree to which the tax code is efficient in raising tax revenue from top executives. The stock option explosion has led to a new and important way for executives to lower their taxes in response to changes in tax rates: by timing their stock option gains. For example, in 1993, it was widely reported in the press that well-known CEOs such as Disney's Michael Eisner pushed their option gains into 1992 in order to avoid paying the higher personal income tax rates implemented in 1993. In an important paper, Goolsbee (1999) argues that the tax shifting between 1992 and 1993 was enormous, and the direct result of the increase in marginal tax rates during this period. After replicating Goolsbee's evidence regarding taxshifting with our data for the 1993 tax reform, we show that no such shifting occurred in response to either of the two tax reforms of the 1980s. Moreover, our evidence indicates that the stock market run-up in 1991 and 1992 was more import than the change in marginal tax rates in causing the large option gains observed in 1992.

This paper proceeds as follows. In the next section, we discuss trends in the level and performance sensitivity of executive compensation. In section three, we describe the tax and accounting rules concerning executive compensation. In section four, we analyze how taxes affect the degree to which options are favored relative to cash. In section five, we examine how the tax advantage of options has changed over time. In section six, we provide evidence on the effect of taxation on the composition of executive compensation. Section seven contains empirical analysis of the million dollar rule. Section eight contains evidence on tax shifting and option gains. Section nine concludes.

\section{Trends in Top Executive Pay}

In this section, we document how top executive pay has changed over time, and discuss how this change has caused the sensitivity of CEO wealth to firm market value to increase substantially. There has been a large increase in the level of CEO pay since 1980 and this growth has been driven by the dramatic increase in stock option grants during this time (Hall and Liebman, 1998). Although salary and bonuses nearly doubled over the period in inflation adjusted terms, the mean value of stock option grants increased by 683 percent. The percentage increase in the median stock option award can not be calculated because the median stock option 
grant was zero in 1980. The median CEO did not receive an annual stock option grant until 1985. Today, nearly all top executives of large companies receive stock options and the average stock option grant is now larger for most top executives than salary and bonus combined.

The (inflation adjusted) growth rate of CEO pay since 1980 -- measured narrowly (cash pay grew at an annual rate of 5 percent per year) or broadly (cash plus option grants grew at almost 9 percent per year) or very broadly (total compensation, including stock and stock option appreciation, grew at 11.5 percent per year) -- has been large relative to virtually all other groups. Indeed, the growth rate of CEO pay since 1980 has been high even relative to the pay increases of other high-income eamers. For example, the cutoff point for being in the top 0.5 percent of adjusted gross income (AGI) increased by about 3.7 percent per year, about half the rate for direct $\mathrm{CEO}$ compensation (excluding stock and option appreciation). The only workers who appear to have had faster compensation growth than CEOs are other "superstars." The annual pay of professional baseball players increased by approximately 9.8 percent per year, while that of professional basketball players rose by 13.9 percent per year.

The increase in stock options has led to a large increase in the equity holdings of top executives, and this in turn has led to a dramatic increase in the responsiveness of executive wealth to firm performance. Nearly all of the pay-to-performance sensitivity of executive compensation comes from equity holdings; for a given increase in shareholder value, changes in the value of an executives stock and stock options are more than 50 times larger than changes in salary and bonus (Hall and Liebman, 1998).

As a concrete example, the estimates in Hall and Liebman (1998) imply that a 10 percent increase in firm value (of the median company in our sample) leads the company to increase the CEO's salary and bonus by about $\$ 25,000$. However, this same 10 percent increase in shareholder value translates into $\$ 1.25$ million increase in the value of the CEO's stock and stock option holdings. ${ }^{1}$

The dramatic rise in the link between CEO wealth and firm performance can be seen in figure 1 , which shows how two measures of this link have increased since $1980{ }^{2}$ The first

1 Stock option grants are also very sensitive to changes in firm performance, mostly because many grants are multi-year plans that hold the yearly number of options constant, and the same number of at-the money options are worth more when the stock price is higher and vice-versa. If stock option grant sensitivity is also included, then about 91 percent of pay-to-performance sensitivity comes from stock and stock option revaluations, 7 percent comes from stock option grant changes, and less than 2 percent comes from changes in salary and bonus. (Hall, 1999). 2 Both measures include only the link created by CEO holdings of stock and stock options, and ignore the smaller 
measure, the Jensen and Murphy (1990) sharing rate (shown on the left scale), is the change in CEO wealth for a $\$ 1,000$ change in firm value. The second measure is the change in CEO wealth for a 10 percent change in firm value (see Baker and Hall, 1998). Since both measures are strongly affected by firm size (the former has a negative correlation and the latter has a positive correlation), the pay-to-performance changes over time are estimated with regression (quantile) analysis that controls for changes in the distribution of firm sizes sample over time. The figure, therefore, shows the increase in the pay-to-performance measures over time for a constant size firm, in this case a $\$ 1$ billion firm (in constant 1998 dollars). The striking fact is that both measures of the pay-to-performance link have increased by nearly a factor of 10 since 1980. These pay-to-performance increases are even larger than those we reported in our earlier paper that analyzed the period 1980 to 1994 because of the large increase in stock option grants combined with the strong stock market performance in the 1994 to 1998 period.

\section{Tax and Accounting Rules}

Stock options give an executive the right but not the obligation to buy a share of the company's stock at a pre-specified price - the "exercise" or "strike" price." Typically, options can not be exercised immediately. That is, they vest (become owned by the executive, who can then exercise if he or she wishes) slowly over time. Common vesting periods are in the three- to five-year range, and options usually vest linearly (e.g. a four year option vests at 25 percent at the end of each year). An executive typically loses any unvested options upon departure. Although options may be exercised as soon as they vest, they do not have to be exercised until they expire or mature. Almost 85 percent of stock option plans have a term of exactly ten years, with virtually all of the remainder being in the five to ten year range. About 95 percent of options are granted "at the money" or at "fair market value," which means that the exercise price at grant date is set equal to the stock price at grant date. The remaining 5 percent are either "discount" options (so called "in the money" options, where the exercise price is below the stock price at grant date) or "premium" options (so called "out of the money" options, where the exercise price is above the stock price at grant date). The holders of options typically do not have dividend rights or voting rights, even on vested options. ${ }^{3}$

amount of pay-to-performance sensitivity that operates through changes in salary, bonus and stock option grants. 3 See Murphy (1999) for details about stock options, and Miller and Scholes (1982) on tax incentives. 


\subsection{Tax Rules and Stock Option Compensation}

Unlike salary and bonus, stock option grants are typically an untaxed event at the time of grant. For the most widely used options - Non-Qualified Stock Options (NQSOs) - executives are taxed at the personal income tax rate on option profits (the difference between that stock price and the exercise price times the number of options) when the options are exercised. The company receives a parallel deduction against corporate income at that point. If the executive continues to hold the shares after exercise, any subsequent appreciation is taxed at the capital gains rate in the usual way. In 1993, an additional feature was added to the tax code (Internal Revenue Code Section 162(M) that disallowed a corporate deduction for any executive pay above \$1 million that is not "performance based." While this rule affects executive salaries, most bonuses qualify as performance based and standard stock options automatically qualify. Therefore, this provision gives companies with highly paid executives an incentive to give more pay in the form of bonuses and stock options, a subject we return to in section 7. A summary description of the tax (and accounting) treatment of cash and option compensation is in Table 1.

A far less common type of option, which is estimated to account for about 5 percent of option grants, is the Incentive Stock Option (ISO). While ISOs are similar to NQSOs in terms of their design, they are crucially different in two respects. First, they have an annual cap of $\$ 100,000$ per executive. Second, the tax treatment of ISOs is different. ISOs are completely untaxed at grant or exercise. It is only at sale that the executive is taxed, and even then the executive is taxed at the lower capital gains tax rate. The disadvantage is that the corporation never gets to take a parallel tax deduction against corporate profits. Thus, ISOs become more attractive as the personal tax rate increases and as the corporate tax rate and the capital gains tax rates fall.

Two other related types of compensation, restricted stock and stock appreciation rights are worth brief discussion. Both, however, are far less common than standard stock options. Restricted stock is payment in the form of restricted shares, the restriction being that the shares vest over time as with options. Unlike options, the shares typically have voting and dividend rights. With regard to taxation, the executive is taxed at the personal rate on the value of the restricted stock as the vesting restrictions lapse. However, the executive may choose to be taxed at the grant date, in which case all subsequent appreciation is taxed at the capital gains rate. The dividends paid to the executive are taxed at the ordinary rate in the usual way. The company 
generally receives a parallel deduction equal to the amount of the executive's income when the executive is taxed. Unlike stock options, restricted stock is not generally considered to be "performance based" and is therefore subject to the million dollar rule (unless the vesting of the restricted stock is performance based, which is sometimes the case).

Stock appreciation rights (SARs) are rights that replicate the payoffs of stock options with a cash transfer. Thus, SARs are simpler than options in that there is no requirement to buy and resell the stock in order to "cash out." SARs generally have the same tax treatment as NQSOs, both to the individual and to the corporation. SARs are relatively rare, however, because they have disadvantageous accounting treatment (described in the next section) relative to stock options, and their main relative advantage vis-à-vis options has been essentially replicated through broker-assisted cashless option exercises - whereby a broker makes a "nanosecond" loan to the executive (to purchase and resell the stock) when the executive wants to "cash in" on option profits. The tax and accounting treatment of ISOs, restricted stock and SARs is summarized in Table 2.

\subsection{The Accounting Treatment of Options}

Unlike cash compensation, which is expensed against earnings, there is generally no expense recognition (at grant, exercise, or sale) for options, whether they be NQSOs or ISOs. As a result, compensation consultants often point out that stock options are the only form of compensation that are free in an accounting sense, but still deductible for tax purposes. Stock options do, however, lead to expense recognition if they are "discounted" ("in the money" at grant date) or if the exercise price and number of options are not known at grant date. For discount options, the difference between the stock price and the market price is expensed over the vesting period. For options with variable terms (e.g. a variable exercise price, vesting that is tied to performance), the options are marked to market and expensed during the time between grant and exercise. Practitioners claim that the accounting treatment of options plays an important role in the design of option program. Thus, plans that have "bad accounting" but are thought by many to have attractive incentive features, are often not even seriously considered by companies. Examples of such potentially attractive plans include indexed options (where a CEO profits only if his firm's share price grows relative to some market or industry benchmark) and option grants that are explicitly performance related, both of which would lead to expenses against earnings. 
Unlike options, restricted stock and SARs do not generally receive favorable accounting treatment. Restricted stock is generally expensed over the period in which the restrictions lapse (usually the vesting period). The magnitude of the expense is the difference between the current stock price and the executive's cost (if any). SARs are marked to market each period and the difference between the stock price and the exercise price is expensed over the outstanding period of SARs.

\section{The Taxation of Executive Pay: Cash versus Options}

Stock-based compensation performs two roles in executive compensation arrangements. First, it helps align the incentives of the executive with the interests of the firm's shareholders. Second, it often enables the firm to compensate the CEO in a way that is more advantageous from a tax standpoint than paying the executive in salary and bonus.

\subsection{Agency Theory and Executive Compensation in the Presence of Taxation}

In standard agency theory models (Jensen and Meckling, 1976), agency costs are the result of the separation of ownership and control. Managers do not have the same incentives as the owners. The optimal incentive contract for managers balances the benefits of high-powered incentives (linking the fortunes of owners and managers through stock and stock options for example) with the costs of loading too much risk on risk-averse managers.

The effect of taxation on the optimal contract (more precisely the share of compensation that is performance related) is ambiguous (even in the absence of deductibility and deferral) because there are offsetting effects. First, by reducing the share of corporate profits received by shareholders, taxes diminish the importance to the shareholders of motivating the CEO. Taken alone, this effect would imply that taxes would be expected to reduce the use of performancebased compensation. Second, because the government shares in the income received by the $\mathrm{CEO}$, the variance of the CEO's income is reduced, raising his utility, and lowering the cost to the firm of providing any given set of incentives. Third, because taxes will lead executives to provide less effort for any given level of incentive based pay, the level of compensation that must be provided to compensate the CEO for effort is reduced, for a given amount of incentive. These last two factors make it cheaper for the firm to offer contracts to the CEO with large incentive components when tax rates are higher, and should therefore increase the use of incentive based pay. Since the net impact of taxation on the level of incentive-based pay is 
ambiguous, agency theory provides no strong predictions about how taxation should affect the optimal composition of option versus cash compensation.

\subsection{The Tax Advantages of Deferral}

While agency theory yields ambiguous predictions about the impact of taxes on the use of options, there-are direct tax advantages of options since options provide executives with a way to defer compensation and thereby lower their taxes. However, because options also lead to a deferral of corporate tax deductibility, the tax advantages from a combined (executive and corporate) perspective are not so straightforward. In this section, we analyze and measure the tax advantages of stock options relative to salary and bonus compensation. We also analyze the tax advantages of NQSOs relative to ISOs. In particular, we show how the tax advantages of options change as personal, corporate and capital gains taxes change. We then show how the tax advantages of options have changed over time in response to changing tax rates.

The crucial tax difference between standard options (NQSOs) and cash payment is that option payouts are deferred, and the two forms of compensation earn different rates of return over the deferral period. Any analysis of the relative tax advantages of two compensation instruments must consider the tax consequences both to the employer and to the employee what Scholes and Wolfson (1992) call the global contracting perspective. Thus, in order to make valid comparisons between the two, we compare the tax burden to the executive, while holding constant the post-tax cost to the company. By keeping post-tax employer costs (in NPV terms) constant, any package that is preferred by the employee is tax advantaged in the global contracting sense.

Under this methodology, a comparison of the tax advantages of options and cash involves comparing a pre-tax cash payment of $\mathrm{P}$ with an option payment that has the equivalent post tax NPV to the company. For NQSOs, it is straightforward to show that a pre-tax payment of $P$ to an executive has exactly the same cost to the company as putting aside $P$ for the purposes of paying stock option payouts later. That is, if a company pays an executive $\mathrm{P}$ today, it will have the same amount of money in $\mathrm{N}$ years as if it had put aside $\mathrm{P}$ today, let it accumulate at the rate of return earned by the firm, and then paid it out (as compensation in the form of option gains ${ }^{4}$ ) with any appreciation in year $\mathrm{N}$.

4 This analysis is not unique to options. Any form of deferred compensation that enables executives to invest inside the firm at a higher post-tax return or without paying capital gains taxes would have similar effects. 
Assume that the pre-tax profit rate is $r$, and the corporate tax rate is Tc. Then, if the company pays $\mathrm{P}$ today, it receives a deduction today of $\mathrm{P} \mathrm{Tc}$, which yields

$$
P T_{c}\left[1+r\left(1-T_{c}\right)\right]^{N}
$$

in $\mathrm{N}$ years, since the benefits of the tax deduction are invested in the company and receive the after-tax corporate rate of return. Conversely, if the company puts $\mathrm{P}$ aside today, then it grows at the after-tax corporate rate of return in $\mathrm{N}$ years to give a tax deduction of

$$
P\left[1+r\left(1-T_{c}\right)\right]^{N} T_{c}
$$

which is the exact same value. Note that the equivalence of these two tax deductions is analogous to the tax-benefit equivalence of front-loaded and back-loaded IRAs.

An executive's payoff in $\mathrm{N}$ years from option profits is equal to $\mathrm{P}$ compounded at the after-tax corporate rate times $1-T_{p}$, where $T_{p}$ is the personal tax rate. Thus, the combined payoffs in $\mathrm{N}$ years of the corporate deduction and the executive's post-tax payoff is:

$$
P\left[1+r\left(1-T_{c}\right)\right]^{N} T_{c}+P\left[1+r\left(1-T_{c}\right)\right]^{N}\left(1-T_{p}\right)
$$

where the first term is the payoff from the corporate deduction and the second term is the executive's payoff.

The payoff to salary and bonus in $\mathrm{N}$ years is more complicated since an assumption must be made about how the executive invests the original cash compensation. For example, if the executive invests in an instrument with taxable interest (e.g. bonds), then the $\mathrm{N}$ year payoff from an investment of $\mathrm{P}$ accumulates at the post-corporate-tax, post-personal-tax rate of return and is:

$$
P\left(1-T_{p}\right)\left[1+r\left(1-T_{c}\right)\left(1-T_{p}\right)\right]^{N}
$$

However, if an executive invests in (non-dividend paying) equities, the investment accumulates at the higher post-corporate-tax rate of return, with the offsetting disadvantage that the capital gains are taxed at the capital-gains rate in year $\mathrm{N}$. So the executive receives 


$$
P\left[1+r\left(1-T_{c}\right)\right]^{N}\left(1-T_{p}\right)-T_{c g}\left[P\left(1-T_{p}\right)\left[1+r\left(1-T_{c}\right)\right]^{N}-P\left(1-T_{p}\right)\right]
$$

where $T_{\mathrm{cg}}$ is the capital gains tax rate. ${ }^{5}$

:..

Thus, putting the equations together, if an executive is paid cash, $P$, and invests $\gamma$ in bonds and 1$\gamma$ in equities, the $\mathrm{N}$ year payoff (including the payoff to the corporation from the tax deduction) is:

$$
\begin{aligned}
& P\left[1+r\left(1-T_{c}\right)\right]^{N} T_{c}+\gamma\left\{P\left[1+r\left(1-T_{c}\right)\left(1-T_{p}\right)\right]^{N}\left(1-T_{p}\right)\right\}+ \\
& (1-\gamma)\left\{P\left[1+r\left(1-T_{c}\right)\right]^{N}\left(1-T_{p}\right)-T_{c g}\left[P\left(1-T_{p}\right)\left[1+r\left(1-T_{c}\right)\right]^{N}-P\left(1-T_{p}\right)\right]\right\}
\end{aligned}
$$

The tax advantage of options versus salary and bonus, therefore, is the difference between the combined (corporate and executive) payoffs in equation (3) and the combined payoffs in equation (6).

\subsection{The Tax Advantage of Options}

We now turn to analysis of how changes in various tax rates affect the tax advantages of options relative to cash compensation. We focus on the case in which the cash earned by executives is invested entirely in equities since equities are tax-favored relative to bonds. The important conclusions of this analysis are not substantively different if we instead assume that a portion of an executive's holdings are invested in bonds.

\subsubsection{The Tax Advantage of Options: Changing the Corporate Tax Rate}

Stock options are tax advantaged relative to cash simply because option payouts are deferred, allowing the executive to invest at the pre-personal tax rate of return (with no capital gains tax at the end) rather than investing at the after-tax rate of return or paying the capital gains tax. Since the advantage of being able to defer taxes is large when the corporate tax rate is low, the tax advantage of options is larger when the corporate rate is low.

5 In practice, executives hold a combination of equities and bond-like instruments with taxable interest. Because equities are tax favored, in the next section we simplify the analysis by assuming that executives hold only equities. Alternatively, we could have assumed that executives hold only less risky bonds since bonds more closely match the risk profile of a stream of tax savings. None of our empirical results are substantively affected by this simplification. 
To illustrate this point, we define the tax advantage of options to be the dollar amount by which total after-tax option payoffs (to the corporation and the executive) exceed the total payoffs from salary, as defined by the difference of equations (3) and (6) assuming that $P$ (the payment to the executive), is equal to $\$ 100$ and $\gamma$ equals 0 (cash compensation is invested in equities). We use a ten-year horizon since most options have a ten-year term. We then calculate how the tax advantage of options changes as the corporate tax rate varies from zero to 100 percent, holding the personal tax rate and the capital gains rate fixed at 40 percent and 20 percent respectively (which approximates current rates).

The top panel of Figure 2 shows the tax advantage of options relative to cash - precisely, the NPV of the total tax advantage of options for a $\$ 100$ payment to the CEO - as the corporate tax rate changes. As expected, the tax advantage of options declines as corporate tax rates increase. At a zero corporate tax rate, the tax advantage of options has an NPV of $\$ 7$. This value is about $\$ 3.5$ at a corporate rate of 40 percent. When the corporate tax rate is 100 percent, the tax advantage of options completely disappears since the benefits of deferred compensation fall to zero since the after-tax return on equities (and therefore the discount rate) falls to zero. The tax advantage of options is the NPV of the tax savings from avoiding the capital gains tax on ten years of appreciation, which is why it is relatively modest even at the 40 percent corporate rate.

\subsubsection{The Tax Advantage of Options: Changing the Personal Tax Rate}

Using the same assumptions as above (but this time holding the corporate rate at 40 percent, the capital gains rate at 20 percent and varying the personal rate), the tax advantage of options declines as personal tax rates rises, as shown in the middle panel of Figure 2. The tax advantage of options is higher at low personal tax rates because the post-tax base that gives rise to capital gains is higher and the advantage of avoiding the capital gains taxes is greater. The tax advantage of options therefore declines linearly as the personal tax rate rises. At a 100 percent personal tax rate, the executive receives nothing in either case, and by construction, the company's tax deduction benefit is the same in NPV terms, so the tax advantage of options falls to zero also.6

6 This is one place where ignoring bond investments has substantive implications. In particular, in the all-bond case the tax advantage of options is nonmonotonic - it rises and then falls -- as personal tax rates rise. 


\subsubsection{The Tax Advantage of Options: Changing the Capital Gains Tax Rate}

The tax advantage of options for various capital gains rates is depicted in the bottom panel of Figure 2 under the same assumptions (this time holding both the personal rate and the corporate rate at 40 percent, while varying the capital gains rate). The tax advantage of avoiding the capital gains tax increases as the capital gains tax rate rises.

\section{How has the Tax Advantage of Options Changed over Time?}

The analysis so far has illustrated how the tax advantage of options varies with the changes in tax rates. In this section, we show how the tax advantage of options has changed over time as tax rates have changed.

\subsection{Top Marginal Tax Rates Over Time}

The evolution of the top marginal tax rates -- personal, corporate and capital gains -- from 1980 to 1998 is shown in Figure 3. In all cases, the top rate (the rate for taxpayers with the highest incomes) is shown, which is not always the highest rate since various anomalies (such as clawbacks of exemptions) sometimes lead to marginal tax rates that are higher than those for the highest income taxpayers.

The top personal tax rate was 70 percent in 1980, falling to 50 percent in 1982 and 28 percent in 1988 following the 1986 tax act. $^{7}$ The top marginal tax rate has since risen to 39.6 percent, but is effectively 42.5 percent since there is a 2.9 percent Medicare surcharge (paid half by the employer and half by the employee) that has no upper limit. The top corporate tax rate has had only one significant change since 1980, falling from 46 percent before the 1986 tax act to 34 percent following the act in 1988 . The top corporate tax rate was increased to 35 percent in 1993. The top capital gains rate has fluctuated between 28 percent (approximately) and 20 percent since 1980 , and is currently at 20 percent.

\subsection{The Evolution of the Tax Advantage of NQSOs}

The tax advantage of options relative to cash, defined in the same way as in section 4, from 1980 to 1998 is shown in Figure 4. The calculations are done using the same assumptions as before (i.e. $\mathrm{N}$ is ten years and cash is invested in equities) and the statutory top marginal tax rates shown in Figure 3 are used. Due to the fall in corporate and personal tax rates, the tax

7 During the early 1980s, the maximum tax on earned income limited the marginal tax rate on the earnings of high earners, so many executives did not face a decline in personal tax rates between 1981 and 1982 . The empirical 
advantage of options increased sharply after the Tax Reform Act of 1986. This increase in tax advantage has largely been reversed in the 1990s as top personal tax rates have crept back up and the capital gains rate has been reduced.

Two key facts emerge from this analysis. First, there is currently only a moderate tax advantage to standard non-qualified stock options - on the order of $\$ 4$ per $\$ 100$ of compensation. This is because the tax advantages to the executive of deferring taxes are largely offset by the tax disadvantages to the company of not being able to deduct option expenses from taxable profits until the executive exercises the options. Second, although the 1986 tax act substantially increased the tax advantage of options, more than half of this increase has been reversed in the 1990s.

\subsection{The Tax (Dis)Advantage of ISOs}

So far the analysis has focused on the tax advantages of NQSOs since they are so much more prevalent than ISOs, which account for only about 5 percent of option grants. The relative scarcity of ISOs can be explained both by their tax status and by their per executive cap of $\$ 100,000$ per year.

Under what conditions are ISOs tax preferred to NQSOs? For a transfer P to an executive, the ISO is always tax preferred by the executive (since the capital gains rate is lower than the personal rate) while the NQSO is always tax preferred from the company's perspective (since an ISO is not deductible). The key issue, however, is the relative advantages of the two types of options from a global contracting perspective. Because ISOs are not deductible, the company is indifferent between setting aside $\mathrm{P}$ in the form of NQSOs today and setting asdie $\mathrm{P}$ $\left(1-T_{c}\right)$ in the form of ISOs. (Since the NPV of the tax deduction for NQSOs is $\mathrm{PT}_{c}$, the NPV of the $\mathrm{P}$ payment is $\mathrm{P}-\mathrm{P} \mathrm{T}_{\mathrm{c}}$ or $\mathrm{P}\left(1-\mathrm{T}_{\mathrm{c}}\right)$ )

Equalizing the post-tax cost of NQSOs and ISOs, we need only look at the payoff of the executive to determine the condition under which each is preferred. The payoff of NQSOs in $\mathrm{N}$ years is:

$$
P\left[1+r\left(1-T_{c}\right)\right]^{N}\left(1-T_{p}\right)
$$

The same payoff for ISOs is:

\footnotetext{
results in this paper are robust to assuming that executives faced a marginal tax rate of 50 percent in 1980 and 1981.
} 


$$
P\left(1-T_{c}\right)\left[1+r\left(1-T_{c}\right)\right]^{N}\left(1-T_{c g}\right)
$$

ISOs, therefore, are tax advantaged if:

$$
\begin{gathered}
\because \\
\mathrm{T}_{\mathrm{p}}-\mathrm{T}_{\mathrm{cg}}>\mathrm{T}_{\mathrm{c}}-\mathrm{T}_{\mathrm{c}} \mathrm{T}_{\mathrm{cg}}
\end{gathered}
$$

Intuitively, ISOs are tax advantaged only if their advantage (the difference between the personal rate and the capital gains rate) is large enough to offset their cost (the disadvantage of not deducting at the corporate rate). Note, however, that the condition is not a simple comparison between the corporate rate the personal rate minus the capital gains rate $\left(T_{p}-T_{c g}>\right.$ $\mathrm{T}_{\mathfrak{c}}$ ).

Figure 5 shows how the tax advantage of NQSOs relative to ISOs, has changed since 1980 as tax rates have changed. Unlike the very modest changes (around 3 to 4 percent) in the relative tax advantages between options and cash shown in Figure 4, the relative tax advantage between NQSOs and ISOs has seen enormous swings. When the top personal rate was 70 percent in 1980, ISOs were tax-favored by a margin of greater than 6 percent. However, by 1982 (following the 1981 tax acts that dramatically lowered the personal tax rate), ISOs became taxdisadvantaged by about 5 percent. By 1988 (following the 1986 tax act), ISOs became taxdisadvantaged by about 18 percent, a dramatic swing. The raising of personal rates coupled with a decrease in the capital gains rate has since reduced the tax disadvantage of ISOs to about $\$ 4$ per $\$ 100$ of pre-tax compensation. Although hard data on ISOs are hard to come by, practitioners (mostly compensation consultants) claim that ISOs were more popular prior to 1982 when they were tax advantaged. Although ISOs are less disadvantageous from a tax standpoint relative to NQSOs than they were in the late 1980s, they are still disadvantageous, so it is not surprising that they have not made a significant resurgence in recent years.

\section{Explaining the Increase in Option-based Compensation}

In this section, we analyze whether changes in tax rates affect the composition of executive compensation, and consider the relative importance of tax factors and corporate governance factors in explaining the increasing share of compensation paid in the form of stock 
options. The numerous changes in tax rates that have occurred since 1980 provide an opportunity to assess whether executive compensation arrangements respond to tax incentives in the way that the tax avoidance model suggests. We test this model using a panel data set of CEOs in large publicly-traded U.S. corporations. Our identification of the tax effects relies on time-series variation in personal, corporate, and capital gains tax rates along with cross-sectional variation in corporate tax rates.

\subsection{Data}

We use a 15-year panel data set of CEOs in the largest publicly-traded U.S. corporations, which is described in Hall and Liebman (1998). The data set covers the years from 1980 through 1994, and combines CEO compensation information from corporate proxies and 10-K filings with stock price and stock return information from CRSP, and accounting data from Compustat. In addition, some compensation data from the 1970s were collected in order to construct measures of the value of stock options held by the CEOs in the first period of the sample. ${ }^{8}$

The feature that distinguishes our data from most other CEO data sets is that with our panel of yearly proxy data on option grants, option gains, and total options held, we are able to calculate the total value of all stock options held by the CEO at a point of time. More importantly, since we have the details about the stock options held (number, exercise price, time to maturity, etc.), we can precisely calculate the change in the value of a CEO's stock option holdings for a given change in firm value.

\subsection{Identification Issues}

The numerous tax changes over our sample period and the specific ways in which changes in personal, corporate, and capital gains rates are predicted to affect the composition of CEO compensation give us unusually rich sources of identification. However, because many of the changes in tax rates would be expected to affect all of the CEOs in our sample in a similar way, we will need to pay particular attention to separating out the tax effects from underlying time-trends and other factors that changed over time. Controlling for underlying trends is particularly important in this study because we are focusing on an outcome -- the use of stock options - that has increased rapidly over the past two decades, and that many practitioners

8 We are grateful to David Yermack for providing us with some of the data for the 1984 to 1991 period. See Yermack [1995] for a discussion of these data. 
believe was importantly affected by non-tax considerations. Thus the tax effects we are trying to explain are deviations from a rising trend.

We take two steps to try to separate out the tax effects from the underlying trend. First, we include key non-tax factors that could potentially explain the increasing reliance on performance-based compeñsation. It has been suggested that the dramatic increase in incentivebased pay is the result of the remarkably poor shareholder returns during the 1970s, which spurred the LBO and takeover movements of the 1980's. According to this story (Kaplan, 1997), shareholders became much more powerful via the rise of institutional investors, even as the LBO and takeover movements waned. Because the influence of institutional investors is thought to be one of the most important mechanisms of strong corporate governance, we use the share of each company's stock owned by institutional investors (defined as institutions with more than $\$ 100$ million under management) as an explanatory variable. ${ }^{9}$ The percentage of shares owned by large institutional investors increased from about 20 percent to almost 50 percent in 1994, an upward trend that closely matches the sharp rise in the share of compensation in the form of options. Indeed, in our sample, the annual average (over all of the firms in our sample) share of stock owned by institutional investors has a correlation of 0.9 with the annual average share of compensation paid in options.

In addition, we include two other variables that proxy for stronger corporate governance. The first is the size of the board. Evidence suggests that boards with smaller numbers of directors reduce the influence of the CEO and better represent shareholder interests (Yermack, 1995). Board size fell by approximately 15 percent between 1980 and 1994 . The second variable is the fraction of the firm's board members who are inside directors or gray directors (non-insiders who have business dealings with the company). Firms with fewer outsiders are less likely to act in the shareholders interests, and we would predict that they would be less likely to have performance-based compensation for their CEOs. The average percentage of inside and gray directors has decreased from about 45 percent in 1980 to about 35 percent in 1994.

Second, we allow for cross-sectional variation in corporate tax rates. Corporate marginal tax rates vary because firms may be eligible for tax-loss-carrybacks and carryforwards, investment tax credits, and the alternative minimum tax (see Auerbach, 1986; Auerbach and Altshuler, 1990; Auerbach and Poterba, 1987; Majd and Myers, 1987). Because these cross-

9. This variable is described in Gompers and Metrick (1998). 
sectional differences imply that different firms should respond differently to a given change in tax rates, they potentially provide us with a way to isolate the tax effects. Firm-specific corporate marginal tax rates are notoriously difficult to calculate from publicly-available data. We use a trichotomous variable that equals zero if the firm has tax loss-carry forwards and negative earnings in a given year, equals 0.5 times the statutory corporate rate if the firm has only one of those conditions, and equals the statutory rate if the firm has neither loss carryforwards nor negative earnings. ${ }^{10}$

The cross-sectional variation in the corporate tax rate may not be exogenous. Firms that perform poorly could face low marginal tax rates and also be particularly likely or unlikely to provide performance-based pay. Because most of our specifications use fixed effects, the correlation we must be concerned about is between changes in firm performance and changes in compensation. We deal with this by controlling for lagged firm stock market performance in our regressions. This should eliminate spurious correlation between tax rates and compensation that is jointly caused by firm performance.

\subsection{Results}

The dependent variable in our regressions is the fraction of a CEO's total annual compensation (measured as the Black-Scholes value of stock options grants plus salary and bonus) that comes from stock options grants. We choose this reduced-form specification because our interest is in the composition of CEO compensation. However, the factors that affect the composition of compensation might also affect the levels, and it will be important to keep this in mind in interpreting our results.

Optimal contracting theory generally makes predictions about the incentives provided by the total amount of firm stock and stock options owned by the CEO. We chose to model the flow of option grants rather than the ultimate performance sensitivity of the CEO's compensation and stock and stock option holdings because we have in mind an adjustment-cost model in which it takes time for a CEO's holdings of stock and stock options to reach the optimal level. ${ }^{11}$ In our

\footnotetext{
10 Graham (1996) presents evidence that the trichotomous variable performs nearly as well as his recommended marginal tax rates from firm Plesko (1999) compares marginal tax rates calculated from Compustat data with actual marginal tax rate than are either the we switch from the trichotomous variable to thichotomous variable. We obtain substantively similar results when 11 See Core and Guay (1999) for variable to the binary variables recommend by Plesko.

See Core and Guay (1999) for evidence that firms adjust in this way.
} 
regressions, we include two measures of the current performance sensitivity of the CEO's wealth to firm performance as explanatory variables to reflect the distance of the CEO's contract from the optimal contract.

Table 3 presents results in which the tax effects are identified solely by variation in tax rates over time. The fraction of annual compensation paid in stock options is regressed on tax variables, corporate governance variables, contract-theory variables, and variables reflecting stock market returns. Both of the regressions in this table include firm fixed effects. In column 1 , the fraction in annual compensation paid in stock options is regressed on the log difference in payoff (the combined payoff to both the firm and the $\mathrm{CEO}$ ) from receiving compensation in stock options rather than salary and bonus, where the payoff calculations are based on statutory marginal tax rates. This variable is defined as the log difference between equation 3 and equation 6 in section 4 . The coefficient on the tax variable is large and statistically significant at the 95 percent level. The point estimate implies that a one percent increase in the payoff difference between stock options and salary and bonus results in a 2.4 percentage point increase in the share of compensation paid in stock options.

The corporate governance variables all have the predicted sign. Firms with a higher fraction of their shares owned by institutional investors, use more performance-based pay (stock options). Firms with large corporate boards, or a large share of inside directors, are less likely to use stock options.

The two contract theory variables are the dollar change in CEO wealth per $\$ 1,000$ change in firm value (Jensen and Murphy, 1990) and the dollar change in CEO wealth per 10 percent change in firm value (Hall and Liebman, 1998). As discussed in Baker and Hall (1998), these two wealth sensitivity measures reflect two different concepts of how closely aligned the manager's incentives are with the interests of the shareholders. In the regression they are meant to measure how far the CEO's existing contract and ownership of stock and stock options is from the optimal level. The negative coefficients on the two variables suggests that firms that are below their optimal pay-to-performance sensitivity are more likely to give more stock options in the current period.

The second column replaces the tax variable motivated by deferral advantages with the three statutory rates. The corporate after-tax share has a positive coefficient, as we would expect, because the tax advantage of stock options increases as the corporate rate falls. The 
coefficient on the personal tax rate is small and not statistically significant. The sign of the coefficient on the capital gains rate is the opposite of that predicted by tax avoidance theory.

Note that these results rely on time series variation alone. This is not a very convincing test. Since the $\log$ difference in payoffs mostly rises over the time period covered in our sample as does the share of compensation paid in options, it is possible that the tax variable is simply reflecting other factors that were changing over this time period that we have not included in our regression. Therefore, it is important to look at specifications that rely on cross-sectional variation in the tax variables.

Table 4 contains specifications that rely on cross-sectional variation in corporate tax rates. The first column repeats the specification from column (1) of Table 3 , but uses the trichotomous measures of firm corporate tax rates in place of the statutory rate in calculating each firm's log difference in payoff from paying compensation in options rather than in salary and bonus. As in the previous table, we find the positive coefficient on the log difference in payoff, just as the theory suggest. However, the coefficient estimate is now much smaller, suggesting that a one percent increase in the log difference in payoff produces a one-tenth of a percentage point increase in the share of compensation paid in options.

Introducing cross-sectional variation in the dependent variable does not eliminate the potentially spurious correlation over time between the tax variable and the share of compensation paid in options. The second column of table 4 isolates the pooled cross-sectional variation in corporate tax rates by adding time dummies and dropping the firm fixed effects. In this specification, the coefficient on the tax variable is indistinguishable from zero. The coefficient on the institutional variable continues to be large and statistically significant. The third column includes both firm fixed effects and time dummies, which tests for a relationship between withinfirm changes in the dependent variable and within-firm changes in each explanatory variable. In this specification, the coefficient on the tax variable is again indistinguishable from zero. The coefficients on the corporate governance variables are also statistically insignificant.

The third column contains a specification that treats the Tax Reform Act of 1986 (TRA86) as a natural experiment. For firms and CEOs facing the statutory corporate tax rate, TRA86 increased the relative payoff to paying compensation in options by 1.7 percent. For a firm facing a zero marginal tax rate, it reduced the relative payoff by 4.5 percent. The reduction occurred because TRA86 reduced the personal tax rate, making salary and bonus more attractive, 
while the decreased corporate rate had no effect on zero-tax rate firms. Thus, we would expect firms facing zero or low marginal tax rates to reduce their use of options after TRA86, while firms facing the statutory rate would be expected to increase them. Few firms face zero marginal tax rates year after year. Therefore, we try to distinguish between firms that often face low tax rates and firms that nearly always face the statutory rate. We define low tax firms as ones whose average marginal tax rate over the 1984 to 1986 period was below $0.24{ }^{12}$ Then we ran a difference-in-differences regression to see if high tax firms increased their use of options more than low tax firms. The interaction between post TRA86 and high corporate tax rates is the key variable. The estimated coefficient on this variable is positive, but small and not statistically different from zero at the 95 percent level.

It is important to note that in this specification as well, the main corporate governance variable, the share of the firm's shares owned by institutional investors, performs as theory would predict. The variable appears to be quite robust. Table 5 presents regressions of the share of compensation paid in stock options on the fraction of the firm's shares owned by institutional investors. Since we have already established that these variables have a strong longitudinal relationship, the regressions here are designed to focus on the cross-sectional relationship between these two variables. The first and third columns present regressions using data only from 1994, and find a coefficient of roughly 0.2 (column 1 contains no other covariates, while column 3 includes all of the other non-tax covariates from the regressions in tables 3 an 4). Since the median share of a firm's stock owned by institutional investors in our sample rises from 19 percent in 1980 to 49 percent in 1994, this coefficient would imply that this factor alone can explain 6 percentage points of the 23 percentage point increase in the median share of compensation paid in options that occurred over this time period. Of course, this variable is only one measure of the strengthening of corporate governance, so the total impact of improved corporate governance could be greater. The second and fourth columns of the table use the entire 1980-1994 sample, and include time dummies to isolate the cross-sectional correlations. Again, there is evidence of a strong cross-sectional relationship between the two variables, although the coefficients are slightly smaller, perhaps reflecting a weaker corporate governance 12 This cutoff was chosen after inspecting the distribution of tax rates, and essentially separates firms that are
always at or near the statutory rate from ones that are sometimes below it. 
role in the earlier period. In sum, there is a strong relationship, in both longitudinal and crosssectional data, between the institutional investor variable and the options percentage variable. ${ }^{13}$

\section{The Million Dollar Rule}

In 1993 section 162(m) of the Internal Revenue Code was enacted, limiting the deductibility of executive compensation in excess of one million dollars, unless the compensation was performance related. Proponents of this legislation argued that it would slow the growth of executive pay and tighten the link between firm performance and executive compensation.

The new provision became effective for tax year 1994 and applies to the CEO and the other four most highly compensated executives in each company. Pay that is performance related such as stock-option grants and bonuses paid for meeting clear performance goals, is not affected by this regulation, provided that it has been approved by shareholders. Thus, the main impact of the provision is to limit the deductibility of salary in excess of a million dollars. Woodlock and Antenucci (1997) studied the proxy statements of 376 firms and documented that most firms responded to the new law by qualifying top executive pay as performance related. Perry and Zenner (1999) identified 25 firms that reduced salaries from above $\$ 1$ million to below $\$ 1$ million and found that 23 of the firms cited section $162(\mathrm{~m})$ as their reason for doing so.

In this section of the paper we investigate whether this provision has affected the level or structure of executive pay, using the Execucomp data base, which contains information on the highest paid executives in each of the firms in the S\&P 500, S\&P Midcap 400 and S\&P SmallCap 600. Between 1993 and 1998 the median salary of the Execucomp executives rose from $\$ 230,000$ to $\$ 306,000$. The median value of total compensation (salary, bonus, and option grants) rose from $\$ 470,000$ to $\$ 882,000$. Limiting the sample to CEOs indicates that the total compensation of the median CEO rose from $\$ 1.1$ million to $\$ 1.8$ million over the period, while the median salary rose from $\$ 441,000$ to $\$ 550,000$. Thus executive compensation clearly continued to rise at a rapid rate after the implementation of the million dollar rule, though perhaps at a slower rate than it otherwise would have.

13 The one specification in which the fraction owned by institutional investors is not significant is in column 2 of table 4, a regression that includes both fixed effects and time effects. 
If the regulation affects behavior, it should have the largest impact on firms whose executives are receiving salaries that are above the limit or just below it. Thus, we might expect to see firms whose executives are receiving relatively high salaries to rely more heavily on performance-based pay and less heavily on salary in the years following the regulation. Perry and Zenner (1999) and Livingston (1999) both find that this is the case. This trend can be clearly identified in the Execucomp data set. For example, over the 1993 to 1998 period the median annualized growth rate of salary for executives whose 1993 salary was below $\$ 500,000$ in the previous year was 8.5 percent. For executives with salary between $\$ 500,000$ and $\$ 700,000$ it was 6.4 percent, for executives between $\$ 700,000$ and $\$ 850,000$ it was 5.0 percent, for executives between $\$ 750,000$ and $\$ 1$ million it was 3.1 percent, and for executives above $\$ 1$ million it was 0.0 percent. ${ }^{14}$

The observation that executives at lower levels of salary had higher growth rates is not very strong evidence of an impact of section $162(\mathrm{~m})$, however, because it is possible that lowsalary executives would have had higher growth rates even in the absence of the provision. To explore whether this is the case, we use Execucomp data from both before and after the law change. Ideally, we would want to have data from many years before the change to examine whether there is an underlying pattern of faster salary growth for low-salary executives. Unfortunately, the Execucomp data begin in 1992 and therefore provide us with only the 19921993 growth rate in compensation to use as a baseline. ${ }^{15}$

We run regressions pooling data from 1992-1993 through 1997-1998 of the annual percentage change in different forms of compensation on a variable, MILLION, that is designed to measure the likelihood that an executive's compensation will be affected by section $162(\mathrm{~m})$. We define MILLION as the minimum of 1 and of the executive's salary divided by $\$ 1$ million in the previous year. Thus, any executive with salary at or above $\$ 1$ million would receive a value of 1 , while an executive with a salary of $\$ 500,000$ would be coded as a $0.5 .16 \mathrm{We}$ include this variable by itself and also interacted with a dummy variable (AFTER) that equals 1 for years 1994 and after. Thus the MILLION variable is designed to pick up any underlying relationship 14 Of the 3137 executives for whom we have complete data between 1993 and 1998,2708 had 1993 salaries below
$\$ 500,000$, while only 35 had 1993 salaries above $\$ 1$ million.

15 The Hall-Liebman data set contains only a combined salary and bonus variable, making it impossible to use it to
analyze this issue. 16 We also ran the regressions (not reported) allowing for a non-linear relationship between MILLION and
compensation growth and obtained substantively similar results. 
between the level of salary and the growth rate of salary, while the interacted one will identify any differential growth rate of salary by income in the period after section $162(\mathrm{~m})$ took effect. We also include a full set of year dummies, the natural logarithm of the firm's market value, and the firm's annual rate of return over the two previous years as control variables. To reduce the sensitivity of our results to outliers, we run quantile regressions and robust regressions.

Table 6 contains our results. The first four columns are for all top executives, while the last four columns focus on CEOs. Columns 1 and 2 present estimates from robust regression for the percentage change in salary and the percentage change in total compensation (salary, bonus, stock grants, and stock option grants). In the salary growth regressions for all executives, the coefficient on MILLION is negative and significant, indicating that there is an underlying relationship between the level of executive compensation and its subsequent growth rate. The coefficient on MILLION*AFTER is negative as well, suggesting that the negative relationship between the level of salary and its subsequent growth rate intensified slightly after 1994. The relatively small magnitude suggests that an executive with a $\$ 1$ million dollar salary would see his salary grow at an annual rate that would be about 0.6 percent slower than an executive earning $\$ 500,000$.

In the second column the coefficient on MLLION*AFTER is essentially zero, suggesting that any decrease in salary brought about by section $162(\mathrm{~m})$ was offset by increases in bonus and stock option grants. The results are similar for the median regressions. There is some evidence of a very small slowdown in growth of salary for executives likely to be affected by section $162(\mathrm{~m})$, but no sign of a change in total compensation. Taken together, this provides evidence of a very small substitution of "performance-related pay" for salary.

The last four columns run identical tests but limit the sample to CEOs. The interaction of MILLION*AFTER continues to be small and negative in the salary regressions. In contrast, the impact of $162(\mathrm{~m})$ on total compensation appears to be positive and fairly substantial (about 15 percentage points per year) in these regressions. That is, the increase in bonus and stock options following the million dollar rule more than offset the very small decline in salary.

All of these conclusions should be interpreted somewhat cautiously because our data provide us with only one pre-1993 control year. Nevertheless, the data are consistent with section $162(\mathrm{~m})$ having led to a very minor slow down in salary growth, and one that is dramatically smaller than what one would conclude without controlling for underlying differential salary 
growth rates at different levels of salary. Since total compensation for CEOs did not decline, and perhaps increased, there is evidence of a minor substitution of performance-related pay for salary in response to the regulation.

\section{Executive Cömpensation and The Elasticity of Taxable Income}

Even if taxes have only a minor impact on executive compensation, the structure of executive compensation is important for tax policy because high-income taxpayers are sources of significant revenue and are the focus of important debates about the efficiency cost of taxation.

Goolsbee (1999) has recently argued that executive decisions to exercise options are highly responsive to intertemporal differences in tax rates created by tax reforms. He claims that much of the apparent decline in taxable income for high income taxpayers between 1992 and 1993 documented by Feldstein and Feenberg (1996) can be explained by executives shifting option gains into 1992 in order to avoid the higher marginal tax rates that went into effect in 1993. By extension, he implies that the high elasticities of taxable income with respect to personal tax rates estimated by comparing the pre- and post-tax reform taxable income of high income individuals reflect intertemporal shifting of income and not permanent effects of taxation. If this is true, then the deadweight loss of taxation is lower, as is the cost of progressivity.

While Goolsbee presents comprehensive evidence that option gains were unusually high in 1992, his identification of the impact of tax rates on the timing of option gains depends on correctly specifying a counterfactual level of options that would have been exercised in the absence of the tax change. He simply assumes a linear time trend. The purpose of Goolsbee's time trend is presumably to account for the increasing use of options over time. However, since options typically require a vesting period of at least a couple of years, a much more direct measure of expected option gains can be constructed, based on the total value of vested options held by the CEO. Since options typically have vesting periods that exceed two years, this total can be treated as exogenous, since it will not be affected by the tax changes.

More generally, the value of options held by the CEO is likely to have a major effect on his exercise decisions. If his options are out of the money, he will not have gains to realize. If there has been a recent run-up in the market, an optimizing CEO may exercise an unusually large 
amount of options in order to diversify his overall portfolio, and if in-the-money options are about to expire, they will be exercised in the current year.

Our evidence suggests that much of the apparent tax shifting can instead be attributed to stock market performance and the timing of past option grants. Using our 15-year panel, we replicate Gooslbee's (1999) result for the 1993 period, but show that the impact of taxes is not present in other time periods. Moreover, even the result for the 1993 period disappears when appropriate controls for past option grants and stock price appreciation are included.

The top three rows of Table 7 present data on the taxable incomes of CEOs in the HallLiebman sample. For these results our panel has been narrowed to include only CEOs whose firm's fiscal years correspond with tax years. In addition, we create a balanced panel for each of the three tax-reform periods by excluding any firm for which there are not complete data for the period surrounding the reform.

The fourth row of the table shows that the 1993 tax act raised the top marginal personal income tax rate from 31.0 to 39.6 percent effective for tax year 1993, with a further increase occurring in 1994 due to the uncapping of the Medicare payroll tax. The top row of the table shows that taxable income was higher in 1992 than for any other year in our sample (all data are in 1994 dollars). Option gains were particularly high in 1992 - more than double their 1991 level and 68 percent higher than their 1994 level. These patterns are consistent with Goolsbee's claim that taxpayers responded to the anticipated increase in marginal tax rates by shifting gains into 1992.

The evidence from the other two tax reforms is less clear, suggesting that there might be factors other than tax rates determining the timing of option gains. ERTA 1981 reduced the top marginal tax rate from 70 percent in 1980 to 50 percent in 1982. However, there is no sign that option gains were reduced in 1980 and 1981 and then increased in $1982 .{ }^{17}$ There was a big increase in option gains in 1983 however. Similarly, the highest year of stock option gains in the period around 1986 was 1987 , a strange year to take gains since taxpayers would have known that the personal rate would be 10 percentage points lower if they waited until the following year. $^{18}$

\footnotetext{
17 As we explained above, for executives covered by the maximum tax on earned income, there was not a decline in
tax rates between 1981 and 1982 .

18 It is possible that the large stock market decline in October 1997 may have prompted some people to exercise
options earlier than they otherwise would have. However, an increase in option exercises typically follow stock
} 
What all the peak years of option gains have in common is that they follow years of strong stock market performance. The fifth row of table 7 shows the average stock market return during the previous year for the firms in our sample. The large value of option gains in 1983 followed a 35.5 percent increase in the stock market. The 1992 boom in option gains followed a 46.6 percent increase in the stock market; the more modest 1987 peak in option gains followed a 19 percent gain (and a 43 percent gain two years before):

Strong stock market performance raises the value of options available to exercise. The sixth row of the table shows the mean value of options held by CEOs at the beginning of the year. All three of the peak years of option gains correspond with peak years in terms of the value of options available for exercise. Since stock market appreciation during the year also increases the value of options available to exercise later in that year, we need to account for current year stock market appreciation as well.

Table 8 contains Goolsbee-style regressions for each of the tax reforms. The first two columns reprint the results from Goolsbee (1999). The third and fourth column replicate his results in our sample. In particular, with a specification similar to his, we are able to replicate his finding that the current after tax share has a positive coefficient and the following year's after-tax share has a coefficient of roughly negative one. Columns (5) through (8) show that this pattern was unique to the 1993 tax reform. Indeed, in the TRA86 regressions the coefficient on the following year's tax rate is positive and significant. Columns (9) and (10) pool all three reforms and fail to replicate the pattern that would reflect intertemporal shifting. 19

It is possible that the ease with which one can shift the timing of option gains is asymmetric. It may be harder to shift option gains forward in time since some options expire and therefore must be exercised now. In addition, options were a much smaller portion of compensation in the early 1980 s, so perhaps the ERTA 81 results are not surprising. Nonetheless, these results cast doubt on the proposition that this is the channel through which spurious estimates of the elasticity of taxable income have occurred for previous tax reforms, and they suggest that we should look harder for alternative explanations for the timing of option gains.

market increases, not declines.

19 The results also fail to suggest large permanent effects of marginal tax rates on taxable income. 
Table 9 attempts to predict options gains using the lagged and current increase in a firm's market value and the value of the options held by the CEO at the start of the year. The two stock market variables strongly predict option gains, while the value of options held has the correct sign in all of the specifications and is significant in the pooled sample even though it is highly correlated with the two stock market return variables. In contrast, the tax-timing explanation fails, even in the 1993 period.

It is important to realize that our results do not invalidate Goolsbee's critique of claims that aggregate revenue data from 1992 and 1993 prove that elasticities of taxable income are large. We have simply given an alternative explanation for why taxable incomes were unusually high in 1992. However, our results do cast doubt on the conclusion that large timing shifts are ubiquitous and capable of explaining away the more careful estimates of taxable income elasticities that have been performed using micro data (e.g., Feldstein, 1995; Auten and Carroll, 1995).

One further point is in order. It is sometimes argued that the combination of increased use of options and the booming stock market explains why federal tax revenues have been so much higher than expected during the 1990s. However, while large option gains increase revenue from the personal income tax, they produce offsetting deductions for corporations. The net impact on revenue is only the difference in the two marginal tax rates times the option gain. While the gap between the personal rate and the effective corporate rate is non-trivial, the impact of large option exercises on total revenue is substantially smaller than the amount by which the exercises inflate personal tax revenue and reduce corporate tax revenue.

\section{Conclusion}

We have described the tax rules for executive pay in detail and analyzed how changes in various tax rates affect the tax advantages of stock options relative to salary and bonus. We find that there is a moderate tax advantage to options - currently about $\$ 4$ per $\$ 100$ in pre-tax executive pay - and that changes in the tax advantage of options over time have had at most a modest impact on the composition of pay. Corporate governance factors, particularly the role of large investors, appear to be more important in explaining the dramatic increase in option pay.

In addition, our evidence suggests that more direct attempts to use tax policy to influence executive compensation have had little effect. We find that the million dollar rule led companies 
to substitute performance-based pay for salary. But our evidence suggests that this substitution was quite modest, and there is no evidence that the total level of pay was reduced. Overall, although the stock-option explosion has dramatically increased the link between pay and performance, this change is due almost entirely to nontax factors. 


\section{References}

Auerbach, Alan J., "The Dynamic Effects of Tax Law Asymmetries," Review of Economic Studies, Volume 53, 1986, pp 451-405.

Auerbach, Alan J. and James Poterba, "Tax Loss Carryforwards and Corporate Tax Incentives,". in M. Feldstein, editor, The Effects of Taxation on Capital Accumulation. University of Chicago Press, Chicago, 1987. Baker, George P and Brian J. Hall, "CEO Incentives and Firm Size," NBER Working Paper
6868, December 1998. Core, John and Wayne Guay, (1999), "The Use of Equity Grants to Manage Optimal Equity
Incentive Levels," Draft.

Core, John E., Hothausen, Robert W., David F. Larcker, (1999), "Corporate Governance, Chief Executive Officer Compensation and Firm Performance," Journal of Financial Economics, 51, pp 371-406. Ellig, Bruce R., CEO Pay: A Historical Perspective, CEO Pay: A Comprehensive Look, pp. 8-
13.

Feenberg, D. and J. Poterba (1993), "Income Inequality and the Incomes of Very High Income Taxpayers," Tax Policy and Economy, v. 7, Poterba ed, MIT Press, Cambridge.

Feldstein, M. (1995), "The Effect of Marginal Tax Rates on Taxable Income: A Panel Study of the 1986 Tax Reform Act," Journal of Political Economy, , (103:3), pp 551-72.

Feldstein, M. and D. Feenberg (1996), "The Effect of Increased Tax rates on Taxable Income and Economic Efficiency: A Preliminary Analysis of the 1993 Tax Rate Increases" in Tax Policy and the Economy, v. 10. Poterba, ed. Pp. 89-117. MIT Press, Cambridge.

Gompers, Paul A. and Andrew Metrick, (1998), "Institutional Investors and Equity Prices," NBER Working Paper Series, No. 6723.

Goolsbee, Austan, (1999), "What Happens When You Tax the Rich? Evidence from Executive Compensation," Working Paper.

Graham, John R., (1996), "Proxies for the Corporate Marginal Tax Rate," Journal of Financial Economics 42, pp. 187-221.

Graham, John R., and Michael Lemmon, (1998), "Measuring Corporate Tax Rates and Tax Incentives: A New Approach," Journal of Applied Corporate Finance 11. 54-65.

Hall, Brian J., (1999), “The Design of Multi-Year Stock Option Plans," Joumal of Applied Corporate Finance, 12, No. 2, pp 97-106. 
Hall, Brian J. and Jeffrey B. Liebman, "Are CEOs Really Paid Like Bureaucrats?" Quarterly Journal of Economics, CXII, no. 3, pp. 653-691, August 1998.

Jensen, Michael C. and William M. Meckling, "Theory of the Firm: Managerial Behavior, Agency Costs and Ownership Structure," Journal of Financial Economics, III (1976), 305 -

Jensen, Michael C. and Kevin J. Murphy, "Performance Pay and Top-Management Incentives," Journal of Political Economy XCVIII (1990), 225-264.

Kaplan, Steven N., (1997), "The Evolution of U.S. Corporate Governance: We Are All Henry
Kravis Now," Draft.

Livingstone, Jane R., "Executive Compensation Contracting and Responses to Increased Tax
Costs," Louisiana State University, June 1999.

Miller Merton H. and Myron S. Scholes, Executive Compensation, Taxes, and Incentives, Financial Economics: Essays in Honor of Paul Cootner, edited by William F. Sharpe and Cathryn M. Cootner, Prentice-Hall, New Jersey.

Perry, Todd, and Marc Zenner,(1999), "Pay for Performance? Government Regulations and the Structure of Compensation Contracts," Working Paper.

Plesko, George A. (1999) "An Evaluation of Alternative Measures of Corporate Tax Rates."
Working Paper. Scholes, Myron and Mark Wolfsen (1992), Taxes and Business Strategy, Princeton, New Jersey:
Prentice Hall, Chapter 10, pp 179-195.

Woodlock, Peter, and Joseph W. Antenucci, "Update: Corporate Responses to Executive Compensation Deductibility Limits," Tax Notes, October 13, 1997, pages 221-226.

Yermack, David, (1995) “Do Corporations Award CEO Stock Options Effectively?” Journal of
Financial Economics, 34, 237-269. 
Table 1

Tax and Accounting Treatment of Executive Compensation:

Cash Payments versus Standard Executive Options.

\begin{tabular}{|c|c|c|c|c|}
\hline & Description & $\begin{array}{c}\begin{array}{c}\text { Taxation at Personal } \\
\text { level }\end{array} \\
\end{array}$ & $\begin{array}{c}\text { Taxation at Corporate } \\
\text { level }\end{array}$ & Accounting Treatment \\
\hline $\begin{array}{l}\text { Salary and } \\
\text { Bonus }\end{array}$ & $\begin{array}{l}\text { Cash payments made to } \\
\text { CEO }\end{array}$ & Taxed as ordinary income. & $\begin{array}{l}\text { Fully deductible. Since } \\
1993 \text {, any pay over } \$ 1 \\
\text { million is not deductible } \\
\text { unless it is performance } \\
\text { based. }\end{array}$ & $\begin{array}{l}\text { Expensed against earnings in the } \\
\text { usual way. }\end{array}$ \\
\hline $\begin{array}{l}\text { Non- } \\
\text { Qualified } \\
\text { Stock } \\
\text { Options } \\
\text { (NQSO) }\end{array}$ & $\begin{array}{l}\text { Options grant the executive } \\
\text { the right, but not the } \\
\text { obligation, to buy shares of } \\
\text { stock at an exercise price } \\
\text { (typically the current stock } \\
\text { price at the date of grant). } \\
\text { The options typically vest } \\
\text { over a 3-5 year period. The } \\
\text { typical maturity is } 10 \text { years } \\
\text { but the manager may } \\
\text { exercise early. Some } \\
\text { options are discount options } \\
\text { (the exercise price is lower } \\
\text { than the stock price at the } \\
\text { grant date). Premium } \\
\text { options are the reverse (the } \\
\text { excrcise price is grcater } \\
\text { than the stock price at grant } \\
\text { date. }\end{array}$ & $\begin{array}{l}\text { The granting of an option is } \\
\text { typically an untaxed event. } \\
\text { Upon exercise, option } \\
\text { profits are taxed at the } \\
\text { ordinary rate. If the } \\
\text { executive continues to hold } \\
\text { onto the shares, the } \\
\text { executive is taxed in the } \\
\text { usual way (at the capital- } \\
\text { gains rate) on any further } \\
\text { appreciation of the share } \\
\text { price. }\end{array}$ & $\begin{array}{l}\text { A parallel tax deduction at } \\
\text { the corporate level is } \\
\text { generally allowed upon } \\
\text { exercise (for the amount of } \\
\text { option profits). Options } \\
\text { automatically qualify as } \\
\text { performance-based pay and } \\
\text { therefore are not subject to } \\
\text { the } \$ 1 \text {-million cap. }\end{array}$ & $\begin{array}{l}\text { There is no expense recognition (at } \\
\text { grant, exercise or sale) for options } \\
\text { if, as is usually the case, the } \\
\text { options are not discounted (in the } \\
\text { money at grant date) and the } \\
\text { exercise price and number of } \\
\text { options is known at grant date. } \\
\text { For discount options, the } \\
\text { difference between the stock price } \\
\text { and the market price is expensed } \\
\text { over the vesting period. For } \\
\text { options with variable terms (e.g. a } \\
\text { variable exercise price, vesting that } \\
\text { is tied to performance), the options } \\
\text { are marked to market and } \\
\text { expensed during the time between } \\
\text { grant and exercise. }\end{array}$ \\
\hline
\end{tabular}

Note: We thank compensation consultants Scott Greenberg and Scott Olsen (both of Towers Perrin) and Frederic Cook (of Frederic W. Cook and Associates) for helpful conversations in understanding the tax and accounting rules. 
Table 2

Tax and Accounting Treatment of Executive Compensation:

Incentive Stock Options (ISOs), Restricted Stock, and Stock Appreciation Rights (SARs)

\begin{tabular}{|c|c|c|c|c|}
\hline & Description & Taxation at Personal level & $\begin{array}{c}\text { Taxation at Corporate } \\
\text { level }\end{array}$ & Accounting Treatment \\
\hline $\begin{array}{l}\text { Incentive } \\
\text { Stock } \\
\text { Options }\end{array}$ & $\begin{array}{l}\text { ISOs are identical to NQSOs } \\
\text { in their design. However, they } \\
\text { have an annual cap of } \\
\$ 100,000 \text { (on the amount that } \\
\text { vests). The tax treatment of } \\
\text { ISOs also differs. }\end{array}$ & $\begin{array}{l}\text { If the usual conditions are met, } \\
\text { there is no tax at grant or } \\
\text { exercise. At sale, all option } \\
\text { profits and subsequent capital } \\
\text { appreciation are taxed at the } \\
\text { capital-gains rate. }\end{array}$ & $\begin{array}{l}\text { If the usual conditions are } \\
\text { met, there is generally no } \\
\text { corporate tax deduction at } \\
\text { grant, exercise or sale. }\end{array}$ & $\begin{array}{l}\text { As with NQSOs, there is } \\
\text { generally no expense } \\
\text { recognition for ISOs (ever). }\end{array}$ \\
\hline $\begin{array}{l}\text { Restricted } \\
\text { Stock }\end{array}$ & $\begin{array}{l}\text { Similar to stock options, but } \\
\text { shares (which vest slowly) } \\
\text { rather than options are granted } \\
\text { to the executive. Unlike } \\
\text { options, the shares typically } \\
\text { have voting and dividend } \\
\text { rights. }\end{array}$ & $\begin{array}{l}\text { The individual is taxed at the } \\
\text { ordinary rate as the restrictions } \\
\text { lapse. However, the manager } \\
\text { may choose to be taxed at } \\
\text { grant date, in which case all } \\
\text { subsequent appreciation is } \\
\text { taxed at the capital gains rate. } \\
\text { Dividends are taxed at the } \\
\text { ordinary rate. }\end{array}$ & $\begin{array}{l}\text { The company generally } \\
\text { receives a parallel deduction } \\
\text { equal to the amount of the } \\
\text { executive's income when the } \\
\text { executive is taxed. } \\
\text { Restricted stock is generally } \\
\text { subject to the million dollar } \\
\text { cap. }\end{array}$ & $\begin{array}{l}\text { Restricted stock is generally } \\
\text { expensed over the vesting } \\
\text { period. The amount } \\
\text { expensed is the difference } \\
\text { between the current stock } \\
\text { price and the executive's } \\
\text { cost (if any). }\end{array}$ \\
\hline $\begin{array}{l}\text { Stock } \\
\text { Appreciation } \\
\text { Rights }\end{array}$ & $\begin{array}{l}\text { Rights that replicate the profits } \\
\text { of stock options. Rarely used } \\
\text { since stock options have more } \\
\text { favorable accounting treatment } \\
\text { (and options provide the same } \\
\text { benefit of cashless exercise } \\
\text { through broker loans.) }\end{array}$ & $\begin{array}{l}\text { Generally have the same tax } \\
\text { treatment as NQSOs. }\end{array}$ & $\begin{array}{l}\text { Generally have the same tax } \\
\text { treatment as NQSOs }\end{array}$ & $\begin{array}{l}\text { Unlike options, SARs are } \\
\text { marked to market each } \\
\text { period, and the difference } \\
\text { between the stock price and } \\
\text { the exercise price is } \\
\text { expensed over the } \\
\text { outstanding period of SARs. }\end{array}$ \\
\hline
\end{tabular}

Note: We thank compensation consultants Scott Greenberg and Scott Olsen (both of Towers Perrin) and Frederic Cook (of Frederic W. Cook and Associates) for helpful conversations in understanding the tax and accounting rules. 
Table 3

Compensation Regressions that Rely on Variation in Tax Rates over Time

Dependent Variable: Share of compensation paid in options

Tax Variables

(1)

$\mathrm{LN}$ difference in payoff 1

LN (1-statutory personal rate)

LN (1-statutory cap. gains. rate)

$2.393(0.349)$

LN (1-statutory corporate rate)

$-0.015(0.034)$

$0.330(0.171)$

$0.399(0.148)$

Corporate Governance Variables

Fraction of firm's shares owned

by institutional investors

$0.043(.029) \quad 0.052(0.028)$

Size of the firm's board of directors.

Fraction of directors who are inside $-0.002(.001)$

$-0.082(.033)$

$-0.003(0.001)$

$-0.092(0.030)$

Contract Theory Variables

$\triangle \mathrm{CEO} W$ per $\$ 1,000 \Delta$ in FV 2

$\triangle \mathrm{CEO} W$ per $10 \% \triangle$ in FV3

Volatility4

LN(Firm market value)

$-0.261(0.095)$

$-5.83(1.89)$

$5.21(4.24)$

$0.019(0.006)$

$-0.247(0.087)$

$-5.54(2.01)$

$2.61(3.69)$

$0.019(0.006)$

Stock Market Return variables

Lagged annual firm stock market return

Lagged annual S\&P500 return

$0.006(0.009)$

$-0.035(0.023)$

$0.003(0.008)$

$-0.029(0.023)$

Regression Diagnostics

Total sample size

Firms

5179

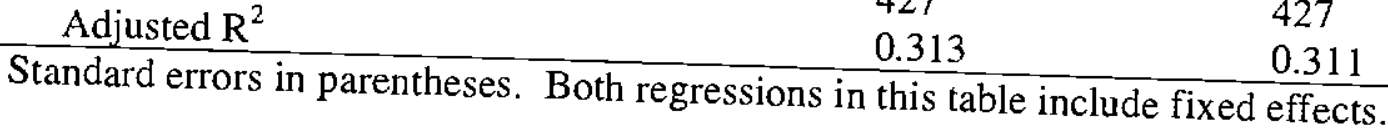

427

5179

427

Standard errors in parentheses. Both regressions in this table include fixed effects.

$1 \mathrm{Log}$ difference in payoff is the log difference in combined firm and CEO after-tax share between paying
compensation in options and paying salary.

2 This variable is the dollar chang salary.

Murphy, 1990).

3 This variable in the dollar charge in CEO wealth per 10 percent change in firm value (see Hall and Liebman,
1998 ).

4 Standard deviation of firm market value in trillions. 
Table 4

Compensation Regressions that Rely on Cross-sectional Variation in Corporate Tax Rates

Dependent Variable is Fraction of Annual Compensation from Stock Options

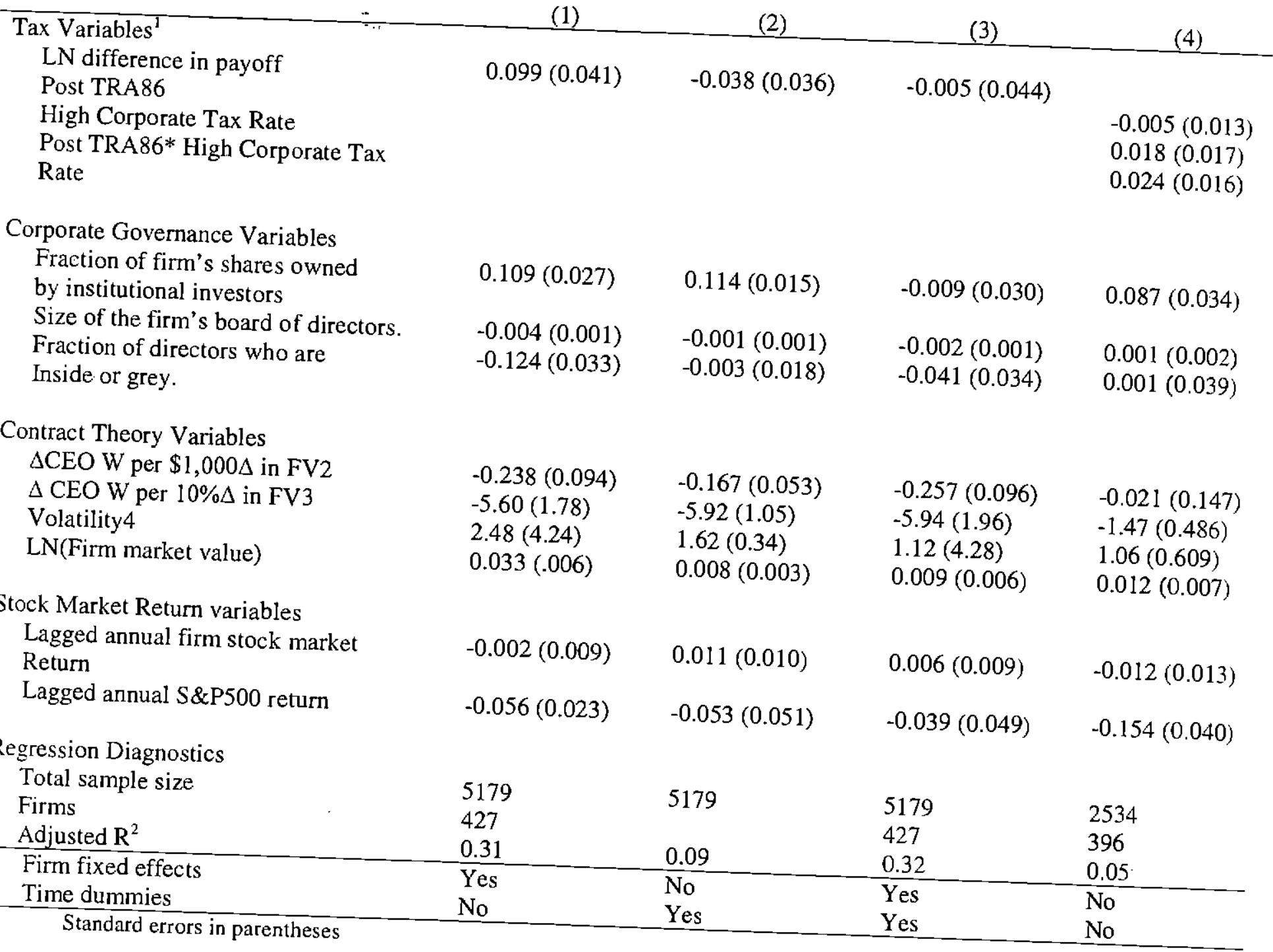

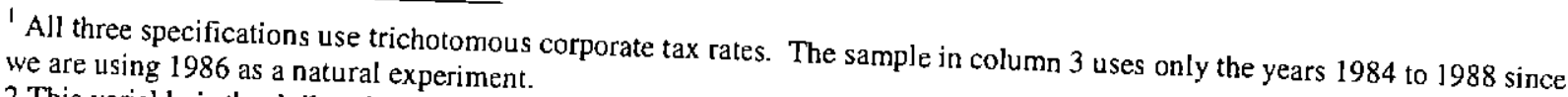

2 This variable is the dollar change in CEO wealth per $\$ 1,000$ dollar change in firm market value (See Jensen $\&$ Muphy,

3 This variable in the dollar charge in CEO wealth per 10 percent change in firm firm market value (See Jensen \& Murphy, 1990).

4 Standard deviation of firm market value in trillions.
} 
Table 5

Large Institutional Investors and Stock Option Compensation

The Cross-sectional Relationship between Institutional Investors and Option Grants

The dependent variable is the share of compensation paid in options

Coefficient on fraction of firm's shares owned by institutional investors

Sample Period

Contract Theory and Stock Market Covariates

Time Dummies
(1)

$$
.217(.067)
$$

1994

No

No
(2)

$$
.145(.014)
$$

1980-1994

No

Yes
(3)

(4)

$.177(.069) \quad .120(.015)$

1994

1980-1994

Yes

Yes

No 
Table 6

The Effect of the Million Dollar Rule on Salary and Total Compensation

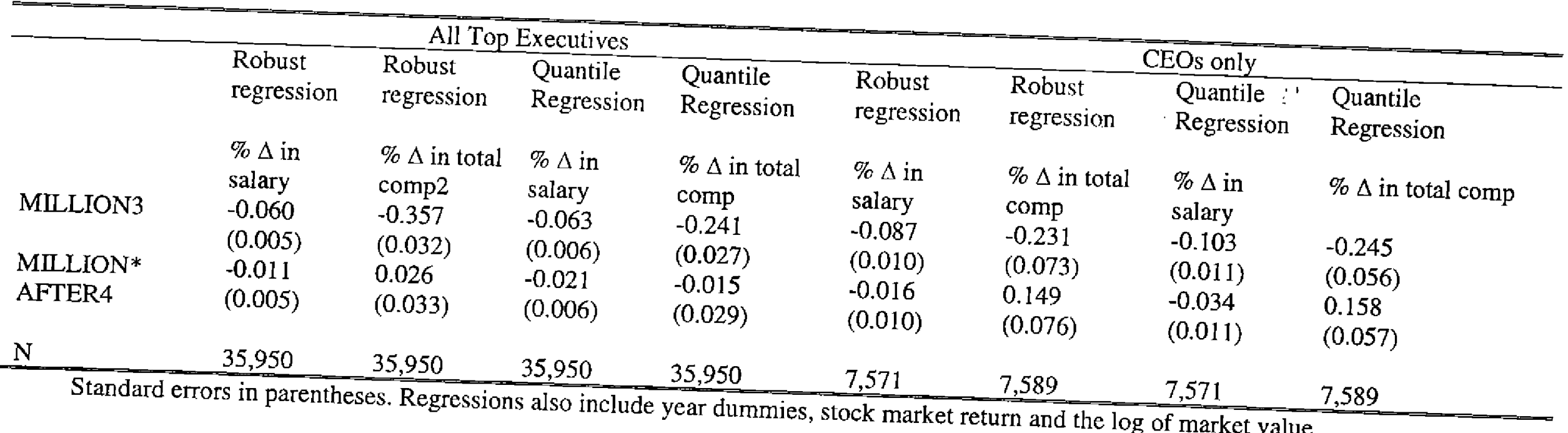

2 Total compensation includes salary, bonus, restricted stock and stock option grants.

3 MILLION is defined as the MIN (1, salary in previous years divided by $\$ 1$ million). 
Table 7

Tax Reform, Stock Market Performance, and the Timing of Option Gains

\begin{tabular}{|c|c|c|c|c|c|c|c|c|c|c|c|c|c|c|}
\hline & \multicolumn{4}{|c|}{ ERTA 81} & \multicolumn{5}{|c|}{ TRA 86} & \multicolumn{5}{|c|}{1993 Tax Act } \\
\hline & 80 & 81 & 82 & 83 & 85 & 86 & 87 & 88 & 89 & 90 & 91 & 92 & 93 & 94. \\
\hline $\begin{array}{l}\text { Mean CEO } \\
\text { Taxable Income } \\
\text { (million) }\end{array}$ & 0.874 & 0.831 & 0.872 & 0.990 & 1.197 & 1.448 & 1.655 & 1.632 & 1.656 & 2.095 & 1.875 & 2.678 & 2.324 & 1.964 \\
\hline $\begin{array}{l}\text { Mean CEO Salary } \\
\text { and Bonus } \\
\text { (millions) }\end{array}$ & 0.648 & 0.672 & 0.679 & 0.724 & 0.837 & 0.917 & 0.959 & 1.058 & 1.052 & 1.028 & 1.020 & 1.070 & 1.209 & 1.262 \\
\hline $\begin{array}{l}\text { Mean CEO Option } \\
\text { Gains (millions) }\end{array}$ & 0.163 & 0.098 & 0.099 & 0.252 & 0.240 & 0.345 & 0.593 & 0.390 & 0.414 & 0.618 & 0.547 & 1.250 & 0.743 & 0.378 \\
\hline $\begin{array}{l}\text { Top Federal } \\
\text { Personal MTR }\end{array}$ & 70 & 69 & 50 & 50 & 50 & 50 & 38.5 & 28 & 28 & 28 & 31 & 31 & 39.6 & 42.5 \\
\hline $\begin{array}{l}\text { Average stock } \\
\text { market return for } \\
\text { firms in the } \\
\text { sample in previous } \\
\text { year (\%) }\end{array}$ & 25.8 & 24.5 & 11.9 & 35.5 & 7.6 & 42.8 & 19.1 & 0.7 & 17.9 & 23.2 & -0.1 & 46.6 & 20.6 & 15.4 \\
\hline $\begin{array}{l}\text { Mean value of } \\
\text { options held at } \\
\text { beginning of year }\end{array}$ & .460 & .706 & .686 & 1.166 & 1.160 & 1.776 & 2.229 & 2.377 & 2.345 & 2.880 & 2.688 & 4.552 & 4.299 & 5.113 \\
\hline $\begin{array}{l}\text { Value of option } \\
\text { gains/Value of } \\
\text { options held }\end{array}$ & .354 & .139 & .144 & .216 & .207 & .194 & .266 & .164 & .176 & .215 & .203 & .275 & .173 & .074 \\
\hline Sample size & 279 & 279 & 279 & 279 & 295 & 295 & 295 & 295 & 295 & 272 & 272 & 272 & 272 & 272 \\
\hline
\end{tabular}

Sample is Hall-Licbman firms with December fiscal years who had complete data for one of the three tax reform periods studied. 
Table 8

Attempts to Replicate the Tax-shifting Result in Other Time Periods

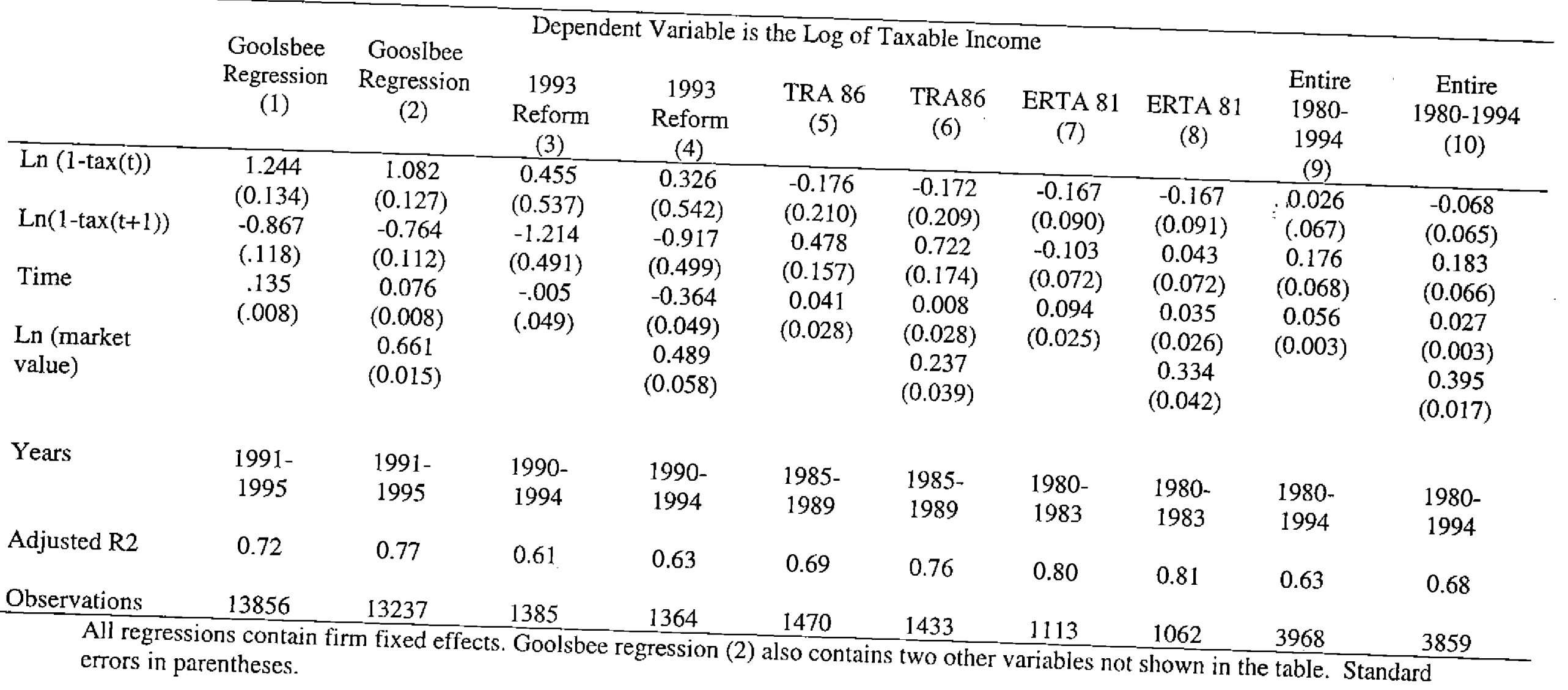


Table 9

Alternative Explanations for the Timing of Option Exercises

The dependent variable is the log of taxable income.

\begin{tabular}{|c|c|c|c|c|}
\hline $\ln (1-\tan (t)$ & $\begin{array}{l}1993 \text { Reform } \\
\text { (1) } \\
\end{array}$ & $\begin{array}{c}\text { TRA86 } \\
(2) \\
\end{array}$ & $\begin{array}{c}\text { ERTA } 81 \\
\quad(3) \\
\end{array}$ & $\begin{array}{c}\text { Entire } \\
1980-1994 \\
(4) \\
\end{array}$ \\
\hline $\operatorname{Ln}(1-\operatorname{tax}(\mathrm{t}))$ & $\begin{array}{c}0.108 \\
(0.324)\end{array}$ & $\begin{array}{c}0.111 \\
(0.136)\end{array}$ & $\begin{array}{l}-0.051 \\
(0.048)\end{array}$ & $\begin{array}{c}0.201 \\
(0.057)\end{array}$ \\
\hline $\operatorname{Ln}(1-\operatorname{tax}(t+1))$ & $\begin{array}{l}-0.134 \\
(0.336)\end{array}$ & $\begin{array}{c}0.573 \\
(0.156)\end{array}$ & $\begin{array}{c}0.125 \\
(0.053)\end{array}$ & $\begin{array}{r}0.150 \\
(0.066)\end{array}$ \\
\hline Ln (market value) & $\begin{array}{c}0.418 \\
(0.061)\end{array}$ & $\begin{array}{c}0.177 \\
(0.039)\end{array}$ & $\begin{array}{c}0.338 \\
(0.046)\end{array}$ & $\begin{array}{c}0.418 \\
(0.163)\end{array}$ \\
\hline Firm's stock market return (t) & $\begin{array}{c}0.298 \\
(0.044)\end{array}$ & $\begin{array}{c}0.268 \\
(0.045)\end{array}$ & $\begin{array}{c}0.214 \\
(0.031)\end{array}$ & $\begin{array}{c}0.258 \\
(0.023)\end{array}$ \\
\hline Firm's stock market return $(t-1)$ & $\begin{array}{c}0.162 \\
(0.041)\end{array}$ & $\begin{array}{c}0.206 \\
(0.008)\end{array}$ & $\begin{array}{c}0.031 \\
(0.029)\end{array}$ & $\begin{array}{c}0.128 \\
(0.021)\end{array}$ \\
\hline $\begin{array}{l}\text { Ln (value of options held by CEO at start of } \\
\text { year) }\end{array}$ & $\begin{array}{c}0.004 \\
(0.003)\end{array}$ & $\begin{array}{c}0.008 \\
(0.003)\end{array}$ & $\begin{array}{c}0.001 \\
(0.002)\end{array}$ & $\begin{array}{c}0.009 \\
(0.001)\end{array}$ \\
\hline $\begin{array}{l}\text { Years } \\
\text { Adjusted R2 } \\
\text { Observations }\end{array}$ & $\begin{array}{c}1990-1994 \\
0.64 \\
1349 \\
\end{array}$ & $\begin{array}{c}1985-1989 \\
0.71 \\
1427 \\
\end{array}$ & $\begin{array}{c}1980-1983 \\
0.82 \\
1036 \\
\end{array}$ & $\begin{array}{c}1980-1994 \\
0.68 \\
3812 \\
\end{array}$ \\
\hline
\end{tabular}


Pay to Performance: The Link Between CEO Wealth and Shareholder Value Since 1980

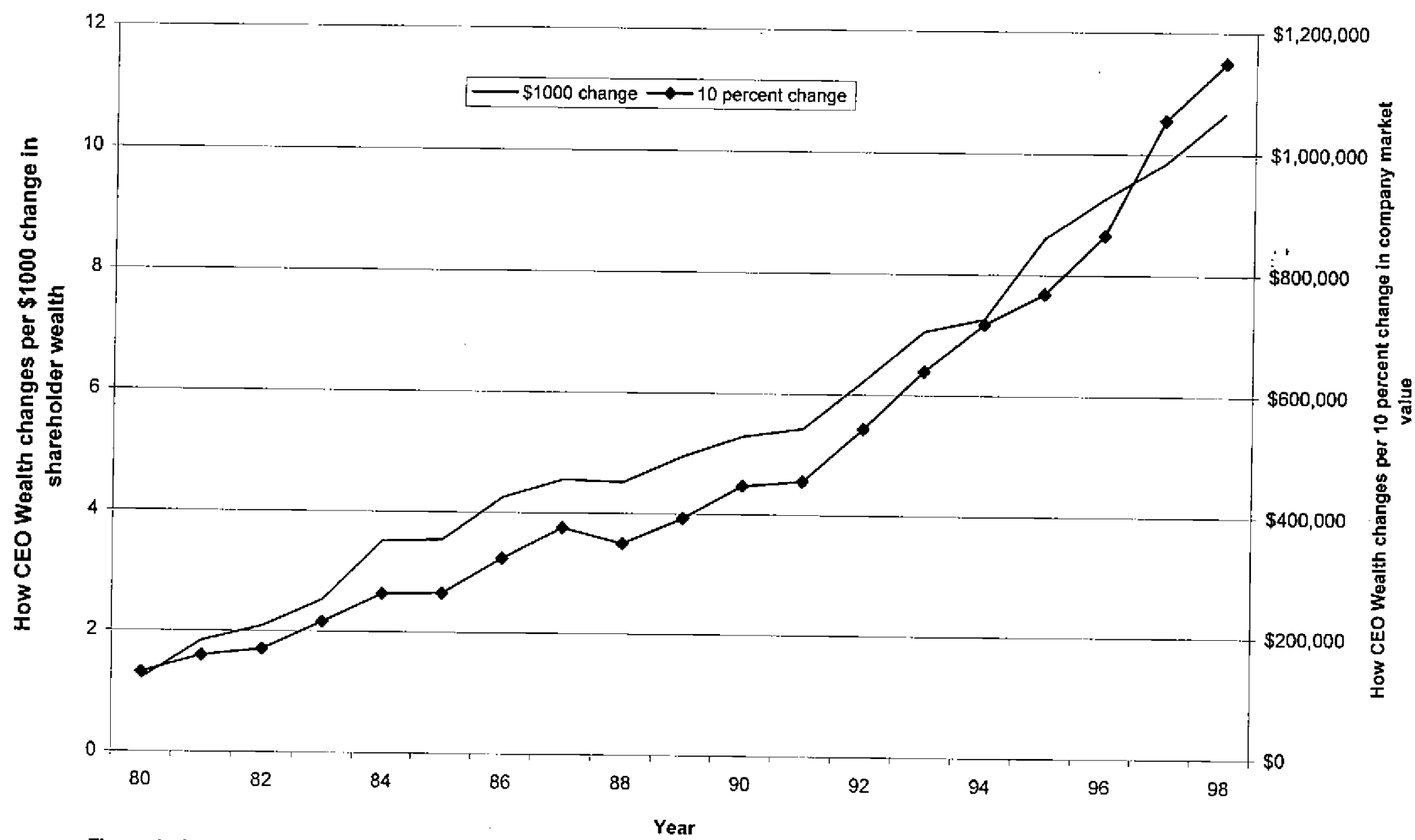

The analysis controls for the changing composition of firm size over time. Thus, these estimates show the pay to performance link for a similarly sized company over time, in this case a company with a market value of $\$ 1$ billion. 
Figure 2

Tax Advantage of Options: NPV of tax advantage of paying $\$ 100$ in options (NQSOs) rather than in cash

Holds constant the personal rate at 40 percent and the capitalgains rate at 20 percent.

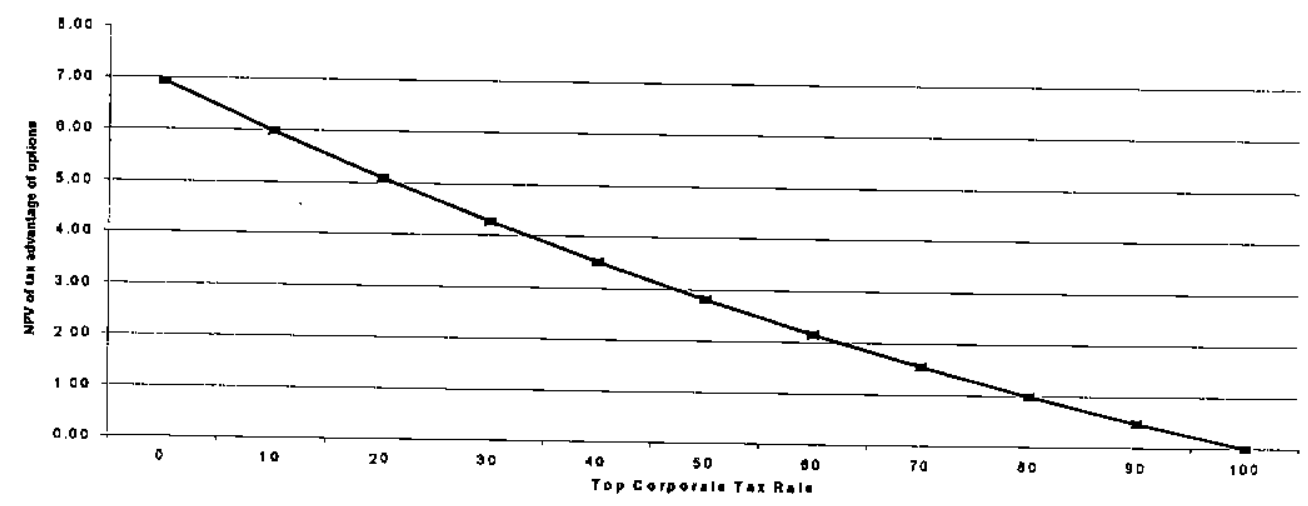

Holds constant corporate rate at 40 percent and capital gains rate at 20 percent

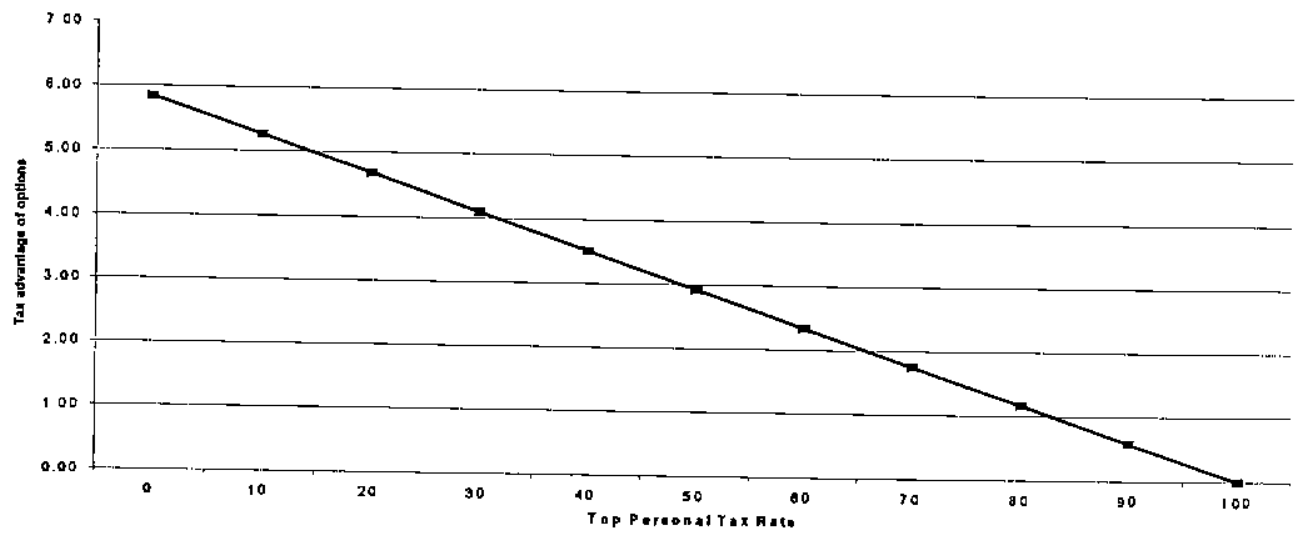

Holds constant the personal and corporate tax rates, each at 40 percent

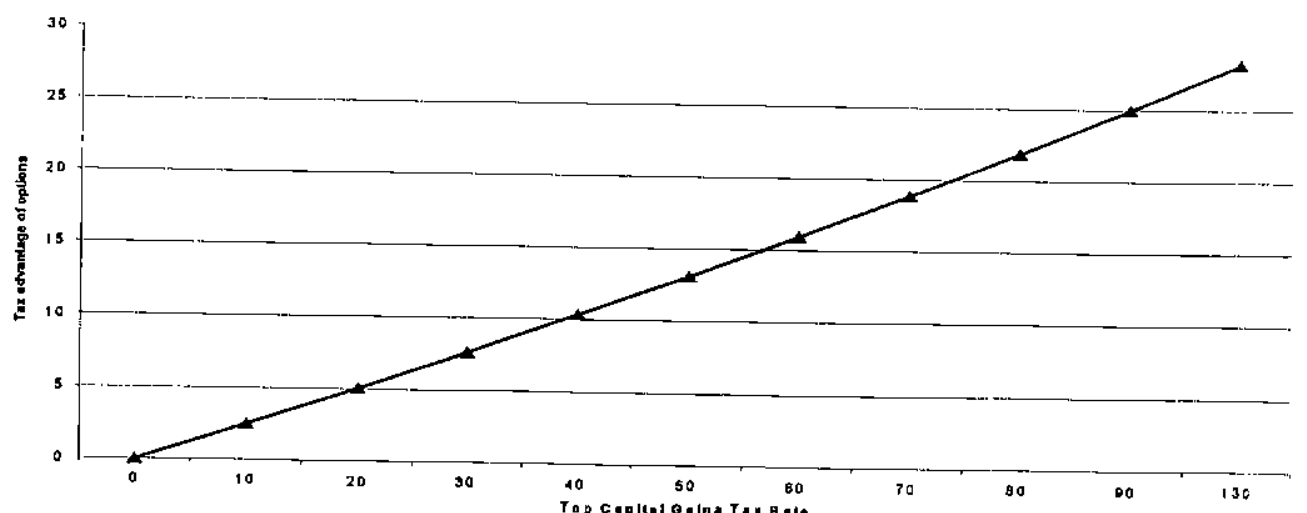




\section{Top Marginal Tax Rates Since 1980}

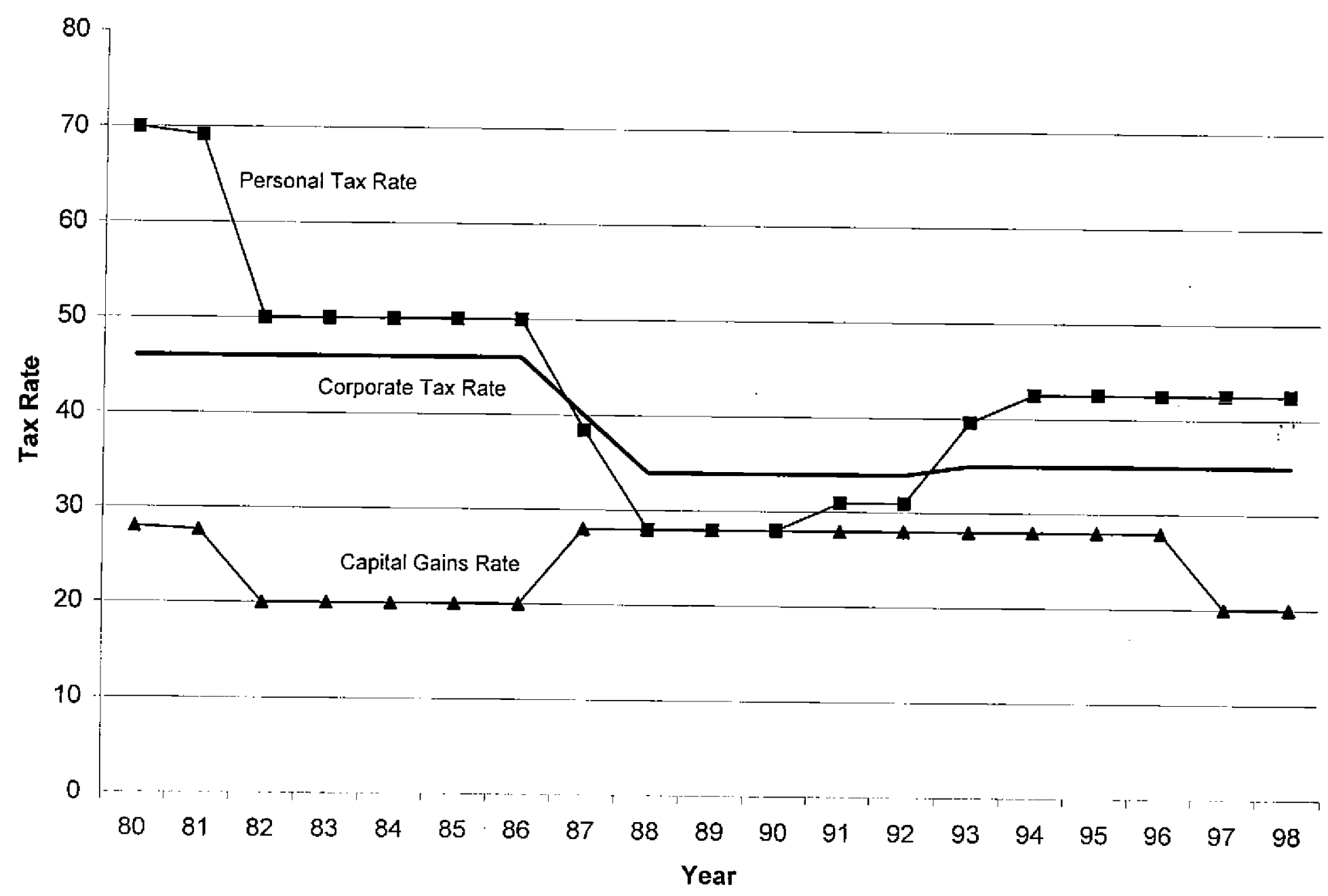


Tax Advantage of Options: 1980 to 1998

NPV of Tax Advantage of $\$ 100$ in Options (NQSOs) Rather Than Cash

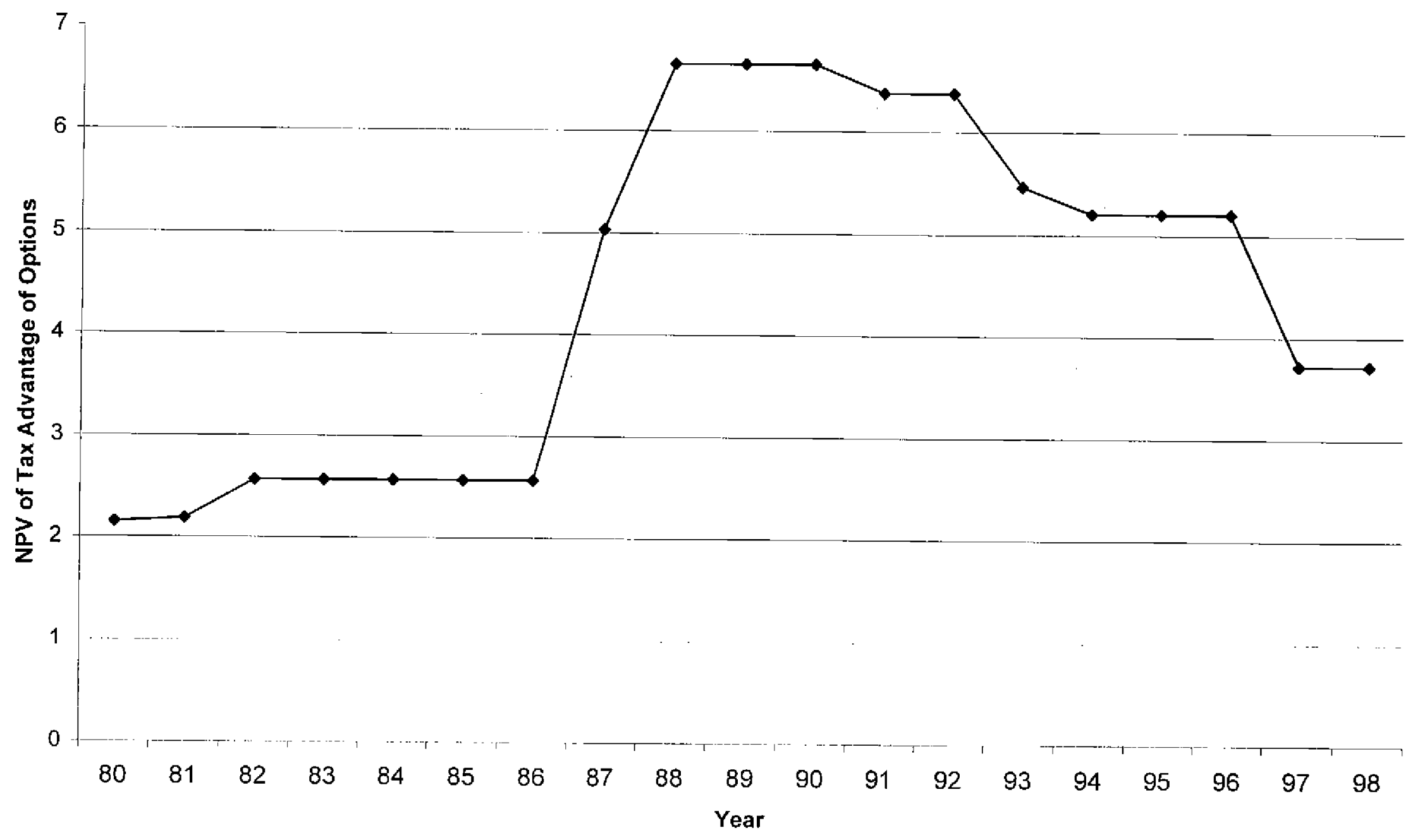


Tax Advantage of NQSOs Relative to ISOs Over Time

NPV of Tax Advantage of $\$ 100$ Payment to Executive: NQSOs minus ISOs

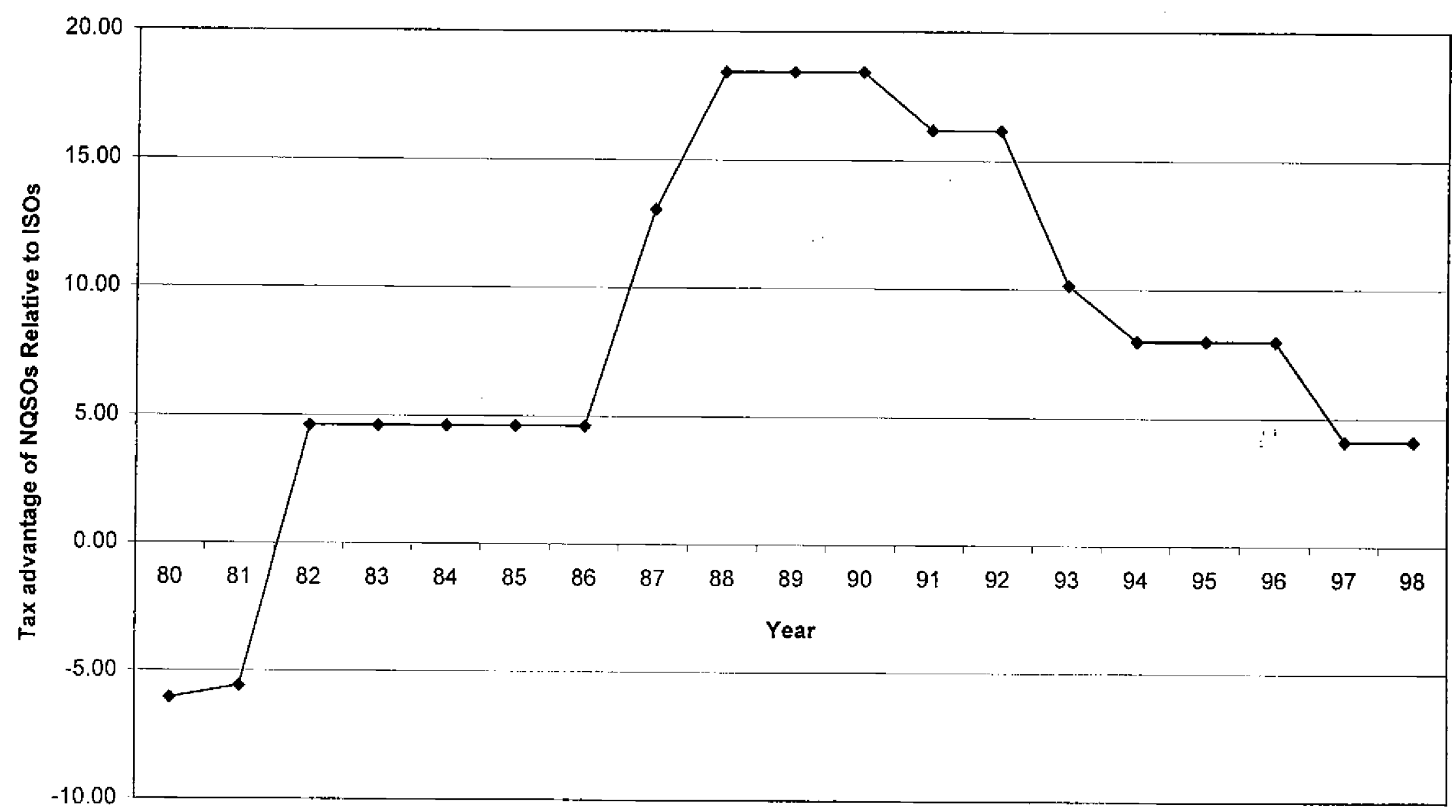

